University of Nebraska - Lincoln

DigitalCommons@University of Nebraska - Lincoln

Estimating accumulation rates and physical properties of sediment behind a dam: Englebright Lake, Yuba River, northern California

\author{
Noah P. Snyder \\ U.S. Geological Survey \\ David M. Rubin \\ Boston College \\ Charles N. Alpers \\ U.S. Geological Survey, cnalpers@usgs.gov \\ Jonathan R. Childs \\ U.S. Geological Survey \\ Jennifer A. Curtis \\ U.S. Geological Survey \\ See next page for additional authors
}

Follow this and additional works at: https://digitalcommons.unl.edu/usgsstaffpub

Part of the Earth Sciences Commons

Snyder, Noah P.; Rubin, David M.; Alpers, Charles N.; Childs, Jonathan R.; Curtis, Jennifer A.; Flint, Lorraine E.; and Wright, Scott A., "Estimating accumulation rates and physical properties of sediment behind a dam: Englebright Lake, Yuba River, northern California" (2004). USGS Staff -- Published Research. 489. https://digitalcommons.unl.edu/usgsstaffpub/489

This Article is brought to you for free and open access by the US Geological Survey at DigitalCommons@University of Nebraska - Lincoln. It has been accepted for inclusion in USGS Staff -- Published Research by an authorized administrator of DigitalCommons@University of Nebraska - Lincoln. 


\section{Authors}

Noah P. Snyder, David M. Rubin, Charles N. Alpers, Jonathan R. Childs, Jennifer A. Curtis, Lorraine E. Flint, and Scott A. Wright 


\title{
Estimating accumulation rates and physical properties of sediment behind a dam: Englebright Lake, Yuba River, northern California
}

\author{
Noah P. Snyder, ${ }^{1,2}$ David M. Rubin, ${ }^{1}$ Charles N. Alpers, ${ }^{3}$ Jonathan R. Childs, ${ }^{4}$ \\ Jennifer A. Curtis, ${ }^{3}$ Lorraine E. Flint, ${ }^{3}$ and Scott A. Wright ${ }^{5}$ \\ Received 19 April 2004; revised 18 August 2004; accepted 20 September 2004; published 18 November 2004.
}

[1] Studies of reservoir sedimentation are vital to understanding scientific and management issues related to watershed sediment budgets, depositional processes, reservoir operations, and dam decommissioning. Here we quantify the mass, organic content, and grain-size distribution of a reservoir deposit in northern California by two methods of extrapolating measurements of sediment physical properties from cores to the entire volume of impounded material. Englebright Dam, completed in 1940, is located on the Yuba River in the Sierra Nevada foothills. A research program is underway to assess the feasibility of introducing wild anadromous fish species to the river upstream of the dam. Possible management scenarios include removing or lowering the dam, which could cause downstream transport of stored sediment. In 2001 the volume of sediments deposited behind Englebright Dam occupied $25.5 \%$ of the original reservoir capacity. The physical properties of this deposit were calculated using data from a coring campaign that sampled the entire reservoir sediment thickness $(6-32 \mathrm{~m})$ at six locations in the downstream $\sim 3 / 4$ of the reservoir. As a result, the sediment in the downstream part of the reservoir is well characterized, but in the coarse, upstream part of the reservoir, only surficial sediments were sampled, so calculations there are more uncertain. Extrapolation from one-dimensional vertical sections of sediment sampled in cores to entire threedimensional volumes of the reservoir deposit is accomplished via two methods, using assumptions of variable and constant layer thickness. Overall, the two extrapolation methods yield nearly identical estimates of the mass of the reservoir deposit of $\sim 26 \times 10^{6}$ metric tons (t) of material, of which $64.7-68.5 \%$ is sand and gravel. Over the 61 year reservoir history this corresponds to a maximum basin-wide sediment yield of $\sim 340 \mathrm{t} / \mathrm{km}^{2} / \mathrm{yr}$, assuming no contribution from upstream parts of the watershed impounded by other dams. The uncertainties and limitations of the estimates of overall sediment quantities are discussed. Implications for watershed management and future reservoir sedimentation studies are also presented. INDEX TERMS: 1815 Hydrology: Erosion and sedimentation; 1857 Hydrology: Reservoirs (surface); 1824 Hydrology: Geomorphology (1625); KEYWORDS: reservoir sedimentation, river restoration, dam removal, sediment transport, Yuba River

Citation: Snyder, N. P., D. M. Rubin, C. N. Alpers, J. R. Childs, J. A. Curtis, L. E. Flint, and S. A. Wright (2004), Estimating accumulation rates and physical properties of sediment behind a dam: Englebright Lake, Yuba River, northern California, Water Resour. Res., 40, W11301, doi:10.1029/2004WR003279.

\section{Introduction}

[2] Reservoirs are vital to the world's economy for their role in electricity generation, flood control, water supply, and recreation, which are all dependent on water storage capacity. However, dams are effective traps of sediment, and capacity is reduced as deltas prograde into reservoirs. In some instances, often associated with active or historical

\footnotetext{
${ }^{1}$ Pacific Science Center, U.S. Geological Survey, Santa Cruz, California, USA.

${ }^{2}$ Now at Department of Geology and Geophysics, Boston College, Chestnut Hill, Massachusetts, USA.

${ }^{3}$ U.S. Geological Survey, Sacramento, California, USA.

${ }^{4}$ U.S. Geological Survey, Menlo Park, California, USA.

${ }^{5}$ U.S. Geological Survey, Flagstaff, Arizona, USA.
}

This paper is not subject to U.S. copyright.

Published in 2004 by the American Geophysical Union. mining activities, dams have been built expressly for their purpose as debris traps. In these situations, reduction in downstream sediment load is the goal. All dams have a profound effect on fluvial transport and downstream riverine morphology, and the rate of sediment infilling is crucial to their long-term utility.

[3] Recently, the Earth science community has shown considerable interest in reservoir sedimentation. Much of this interest is concerned with the role of river management in changing sediment delivery rates to the world's coastlines and oceans [e.g., Syvitski, 2003; Vörösmarty et al., 2003], and in documenting the effects of decreased sediment load and altered hydrographs on downstream fluvial systems [e.g., Rubin et al., 2002; Grant et al., 2003; Magilligan et al., 2003; Wright and Schoellhamer, 2004]. Several researchers have used reservoirs as laboratories for understanding depositional processes [e.g., Kostic et al., 2002; Twichell et al., 2005]. Other workers have used the sediment deposited 
behind dams to understand transport and erosion rates at the watershed or regional scale [e.g., Ambers, 2001; Dadson et al., 2003; Verstraeten et al., 2003], in much the same way that many studies have used lacustrine sediments as a record of processes or climatic history [e.g., Dean et al., 2002; Noren et al., 2002]. These recent investigations demonstrate the importance of collecting high-quality data sets documenting the rates, physical properties, and morphology of sediment accumulation behind dams [e.g., Smith et al., 1960; Ambers, 2001], although relatively few detailed studies have been published.

[4] As dams age they may become unsafe or no longer useful; as a result dam removal has become a viable management option in some cases [e.g., Pejchar and Warner, 2001; Aspen Institute, 2002; Heinz Center, 2002; Doyle et al., 2003]. Old dams may become structurally unsound and need to be removed for public safety reasons. Maintenance costs of dam operations can become greater than the economic benefits to the dam operator. Increasing awareness of the importance of rivers as corridors for migration of aquatic species and transport of nutrients and sediment has resulted in new research on the role of dam removal in river restoration (e.g., series of articles given by Hart and Poff [2002]). In every case, a key aspect of the design of a dam removal project is the management of sediment trapped behind the dam. In particular, the quantity, grain size, and chemistry of the impounded material must be assessed to design a dam decommissioning plan and make reasonable predictions its cost and impact. Here we present the results of a thorough quantification of the contents of a reservoir in the Sierra Nevada foothills of northern California, accomplished by extrapolating data from an extensive coring campaign. We also discuss the limitations of the methods and results, and their implications for a local habitat restoration program and future reservoir studies. This contribution represents one of the first published attempts to quantify fully the sedimentary contents of a medium-sized reservoir, and we anticipate many similar studies will be done in the years to follow.

\subsection{Yuba River and Englebright Dam}

[5] The Yuba River, in the northwestern Sierra Nevada of California (Figure 1), is a classic laboratory for fluvial transport studies because of the vast quantity of sediment that was released during a period of intensive hydraulic gold mining in the late 19th century [Gilbert, 1917; James, 1993]. The river drains an area of $3468 \mathrm{~km}^{2}$ that ranges from over $3000 \mathrm{~m}$ elevation on the Sierra Nevada crest to $27 \mathrm{~m}$ at the confluence with the Feather River in the Central Valley near Marysville. The Yuba watershed, particularly the South Yuba River, was the locus of intensive hydraulic mining with the mobilization of $\sim 522 \times 10^{6} \mathrm{~m}^{3}$ of sediment, the largest single source of any of the tributaries of the Sacramento River [Gilbert, 1917]. Because the river had insufficient capacity to transport all of this material, riverbed elevations were raised up to $40 \mathrm{~m}$ in parts of the watershed. During hydraulic mining, mercury was used to extract gold from sluiced placer deposits, and as much as $10-30 \%$ of this mercury was lost into tailings deposits [Alpers and Hunerlach, 2000, and references therein] (see http:/ca.water.usgs.gov/mercury/fs06100.html). Since the 1880s Sierra Nevada rivers have been transporting sediment from sources including these lag deposits, smaller-scale, continued hydraulic mining, and erosion of hillslopes and other abandoned mines [James, 1993, 1999, 2004].

[6] Englebright Dam (Figure 2) is $80 \mathrm{~m}$ tall and impounds a narrow, medium-size reservoir (original capacity $86.0 \times 10^{6} \mathrm{~m}^{3}$ ). It has an upstream contributing area of $2870 \mathrm{~km}^{2}$, and was completed in December 1940 by the California Debris Commission (CDC). Its primary purpose was to contain sediment from anticipated future hydraulic mining activity in the Sierra Nevada foothills (although this mining activity did not resume after World War II), which would help mitigate flood risk in the Central Valley around Marysville. At present, the reservoir is a popular destination for recreational boaters and campers and plays an important role in regional hydroelectric generation. The dam is located $36 \mathrm{~km}$ upstream of the confluence of the Yuba and Feather rivers (Figure 1). Daguerre Point Dam is between Englebright Dam and the Feather River. It is also a sedimentation basin, built in 1906 by the CDC. It impounds a reservoir volume of $74000 \mathrm{~m}^{3}$, and has been entirely filled with sediment for most of its history [Hunerlach et al., 2004].

[7] The upper Yuba River includes the three branches: the North Yuba, Middle Yuba and South Yuba rivers (Figure 1). The watershed is heavily managed, with various intrabasin and interbasin water diversions and numerous impoundments. Therefore not all of the water and sediment transported in the upper Yuba River system reaches Englebright Lake. The most significant impoundment in the watershed is New Bullards Bar Dam, a large (197 m tall) structure built in 1970 on the North Yuba River. New Bullards Bar Reservoir has an upstream contributing area of $1269 \mathrm{~km}^{2}$, and receives water diversions from the Middle Yuba River. It is a major hydropower, flood control, and recreational facility. The completion of New Bullards Bar Dam caused the inundation of Bullards Bar Dam, a structure built on the North Yuba River in 1924. The largest dam in the Middle Yuba watershed is Jackson Meadows Dam (60 m tall), which was completed in 1965. Jackson Meadows Dam was built just upstream of the smaller Milton diversion structure (11 m high), which has a contributing area of $103 \mathrm{~km}^{2}$, and was completed in 1928. The South Yuba River also has several dams. The lowermost of these is Lake Spaulding Dam (84 m tall, $306 \mathrm{~km}^{2}$ upstream area), which was completed in 1913, and serves to divert water out of the Yuba system into the Bear and American River watersheds to the south. For the purposes of the sediment yield calculations presented herein we assume that the structures listed above trap all non-wash-load material, therefore reducing the contributing area for sediment to Englebright Lake to $1192 \mathrm{~km}^{2}$.

\subsection{Upper Yuba River Studies Program}

[8] The Upper Yuba River Studies Program (UYRSP) is an investigation of the feasibility of introducing anadromous fish species to the Yuba River system upstream of Englebright Dam. The UYRSP study area (Figure 1) does not include the North Yuba River watershed because New Bullards Bar Dam blocks fish passage. To achieve the UYRSP objective of fish passage beyond Englebright Dam, future management scenarios under consideration include lowering or removing the dam. Any reduction in size of the dam would result in some change in the sediment regime of the lower Yuba River, and could cause the release of material presently stored in Englebright Lake. This 


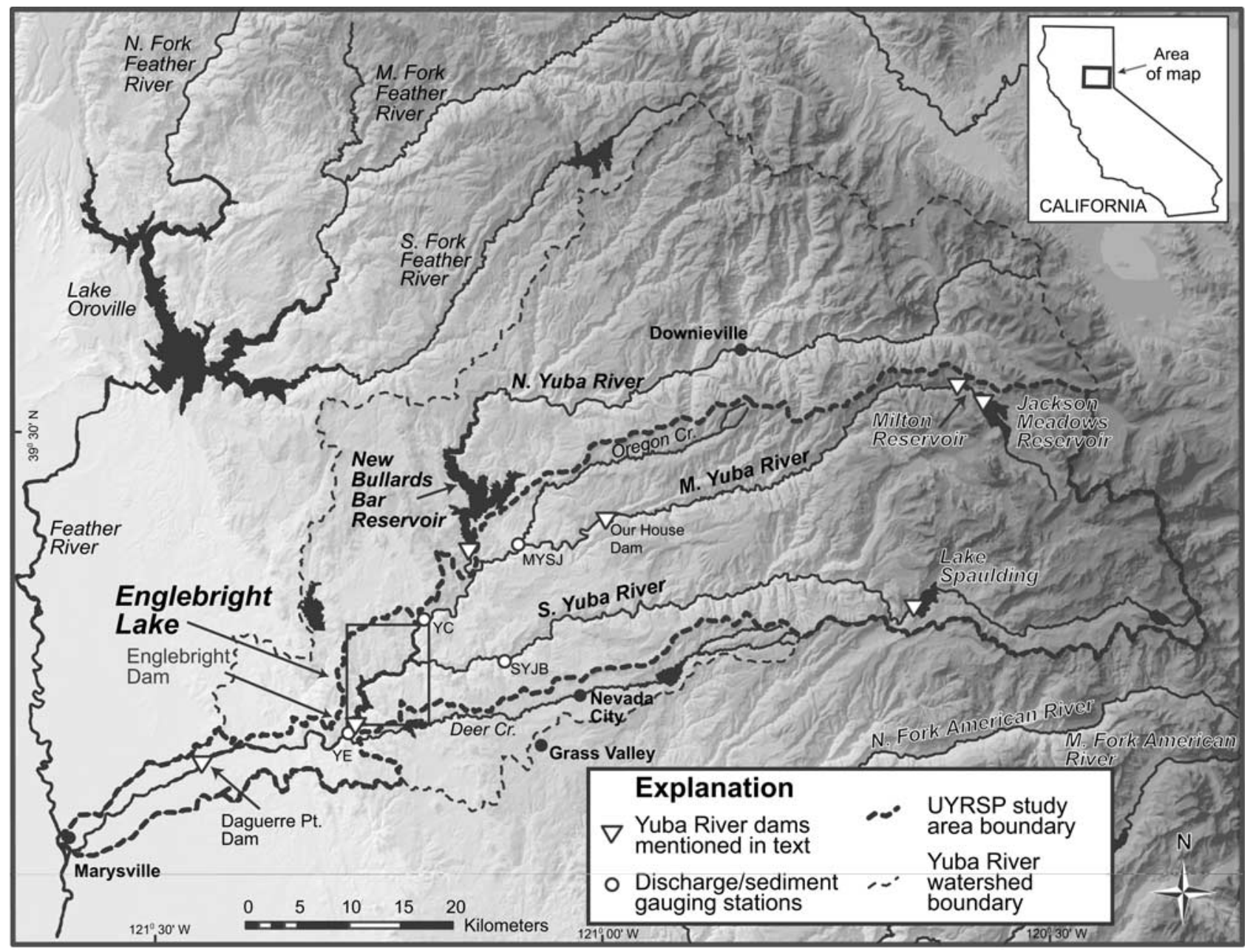

Figure 1. Map of the Yuba River watershed showing the location of the Upper Yuba River Studies Program (UYRSP) study area (watersheds of the Middle Yuba and South Yuba rivers and the lower Yuba River). Shading indicates relative elevations (light is lower, dark is higher). The box shows the region around Englebright Lake included in Figures 3 and 4. Abbreviations for gauging station labeling are MYSJ, Middle Yuba River near North San Juan (U.S. Geological Survey station number 11410000); YC, Yuba River below new Colgate power plant (11413700); SYJB, South Yuba River at Jones Bar (11417500); YE, Yuba River below Englebright Dam (11418000).

increased sediment load could exacerbate existing hazards in the lower Yuba River area, such as flooding and mercury bioaccumulation in fish species. Therefore the ability to make accurate predictions of the fate and transport of the material stored in Englebright Lake is critical to assessing the feasibility of various future dam management scenarios. The research presented herein is motivated by the need to quantify the three-dimensional distribution of sediment grain size in the reservoir.

\subsection{Approach and Scope}

[9] This contribution quantifies the mass, grain size, and accumulation rates of the material deposited in Englebright Lake since closure of the dam in 1940. The internal stratigraphy of the deposit is considered over a large scale, not the details of individual layers or events. Rates of sediment transport and the development of depositional morphology are calculated over the entire 61 year history of the reservoir from 1940 to 2001. This work has three intended purposes. First, we present high-quality estimates

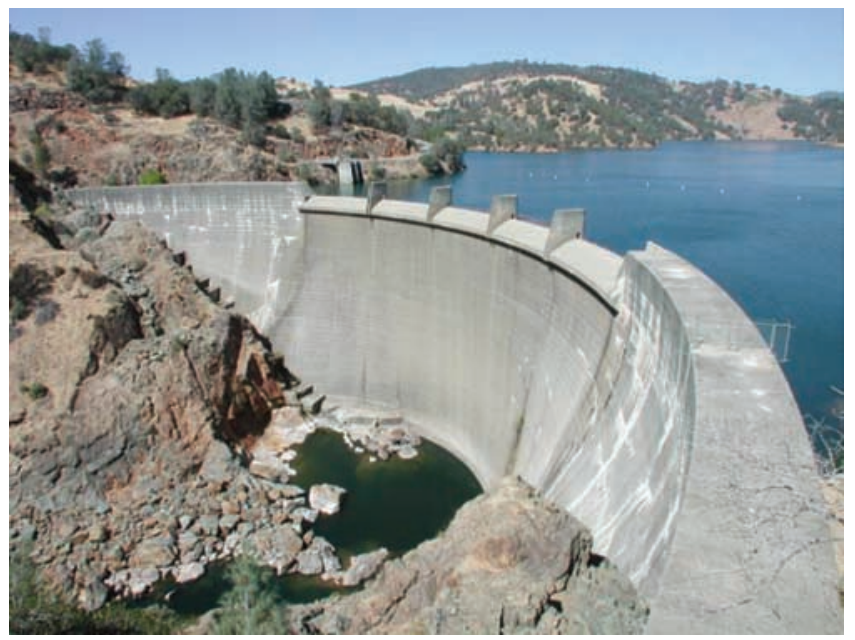

Figure 2. Photograph of Englebright Dam. 
of the physical contents and deposition rates of the material stored in the reservoir, based on two techniques for extrapolating from layers of cored sediment to the surrounding volume of material. Second, the resulting calculations will aid in decisions related to the future management of Englebright Dam. Specifically, these data will be used in future studies to: (a) test and calibrate an upstream watershed sediment model; (b) quantify the relationship between sediment grain size and chemistry (e.g., mercury concentration); and (c) serve as a boundary condition for modeling downstream transport of sediment, mercury and other contaminants under future dam management scenarios. Third, we offer suggestions based on our methods and results intended to be instructive and useful to other researchers working in reservoir settings.

\section{Reservoir Data Collection}

[10] The data used for this study can be divided into two broad categories: mapping topographic surfaces, and coring of reservoir sediments. The various data sets collected relevant to this study are outlined briefly below, and described in detail elsewhere [Childs et al., 2003; Snyder and Hampton, 2003; Snyder et al., 2004a, 2004b] (see http://geopubs.wr.usgs.gov/open-file/of03-383; http:// geopubs.wr.usgs.gov/open-file/of03-397; http://pubs.usgs. gov/of/2004/1080; http://pubs.usgs.gov/of/2004/1061).

\subsection{Reservoir Sediment Volume}

[11] Volumetric accumulation of material in reservoirs can be estimated by differencing bathymetric surveys taken at different times [Morris and Fan, 1998]. This simple method is an effective means of quantifying infilling rates, particularly in reservoirs where detailed maps of the predam river topography are available. For Englebright Lake, Childs et al. [2003] prepared an isopach map (Figure 3) and produced volume estimates by differencing two digital grids of the reservoir floor elevation. The first was derived from a 1939 U.S. Army Corps of Engineers topographic map of the Yuba River valley in the location of the future reservoir. The second grid was derived from a May 2001 acoustic fathometer survey of the reservoir. A full discussion of the methods used to create these grids, as well as a comparison of the grid surfaces with coring is provided by Childs et al. [2003]. The reservoir accumulated $21.9 \times$ $10^{6} \mathrm{~m}^{3}$ of sediment between December 1940 and May 2001. This estimate has an uncertainty of approximately $4.5 \%$, based on the quantity of material apparently eroded from the reservoir sidewalls [Childs et al., 2003]. This volume of stored material represents a reduction in storage capacity of $25.5 \%$. For the purposes of the volumetric calculations, Childs et al. [2003] divided the lake into 8 regions based on the midpoints between the 7 deep-coring sites (described below), and the unsurveyed branches at the upstream end of the reservoir on the Yuba River and South Yuba River (Figure 4). Here we present calculations of the mass, organic content, and grain size of the material deposited in each of these regions.

\subsection{Reservoir Sediment Coring, Sampling, and Processing}

[12] To characterize the geochemical and physical properties of the reservoir sediments, three sediment sampling campaigns were conducted in 2002 (Figure 4): (1) a reconnaissance effort using grab-sampling equipment in April; (2) a large mobilization with a hydraulic-piston coring rig in May and June (called the "deep coring campaign," below); and (3) a shallow coring project in October, focusing on the geochemistry of surficial sediments. During the shallow coring campaign, 29 box cores and 21 gravity cores were taken at 11 locations throughout the reservoir, including series of cores along transverse sections on the lake floor at 3 locations. These transects provide a means of testing the degree of lateral variability in sediment grain-size and geochemical properties. The sampling strategies and processing methodologies for all three campaigns are detailed by Snyder et al. [2004a, 2004b].

[13] The objective of the deep coring project was to sample the entire postdam sediment thickness in a variety of locations in Englebright Lake. Most of the results presented herein derive from this campaign, which was completed by the U.S. Geological Survey and the DOSECC (Drilling, Observation, and Sampling of the Earth's Continental Crust) research drilling company, with assistance from the Limnological Research Center of the University of Minnesota. In total, 30 boreholes were attempted at 7 sites, $335 \mathrm{~m}$ of sediment was cored, and $288 \mathrm{~m}$ was recovered, for a recovery rate of $85.9 \%$ [Snyder et al., 2004b]. At least two complete sedimentary sections were recovered at 6 of the 7 coring sites (Table 1). At each coring location spaced along the longitudinal axis of the reservoir (Figure 4), 2 to 5 boreholes were drilled approximately 5$10 \mathrm{~m}$ apart, primarily to assure complete recovery of the entire sedimentary section in each location by collection of overlapping material. From these parallel boreholes, we collected an approximately continuous, composite representation of the stratigraphy (Figure 5). Each sampled interval included $10-100 \mathrm{~cm}$ of material, with the length determined by stratigraphic layering (each subsample could include one or more beds). Density, moisture content, grain-size distribution and organic content analyses of these 230 subsamples (the "Y series" subsamples of Snyder et al. [2004a]) are the basis for this study. Grain-size distributions were measured using a Coulter LS100Q laser particle-size analyzer and sieves. Organic content was estimated by loss-onignition analysis. The methods, uncertainty analysis, and results of the grain-size and organic content analyses for all three coring and sampling campaigns are detailed by Snyder et al. [2004a].

\subsection{Description of Reservoir Sedimentary Architecture}

[14] The sediment package within Englebright Lake exhibits a deltaic form shaped by the long, narrow geometry of the reservoir (Figures 4 and 5). The topset, upstream part of the reservoir is relatively flat (mean gradient $0.13 \%$ or $0.07^{\circ}$ ). The downstream part includes a steep foreset slope (maximum gradient $6.55 \%$ or $3.75^{\circ}$ ) and a lower bottomset section reaching to the dam with a gradient parallel to the predam river $\left(0.45 \%\right.$ or $\left.0.26^{\circ}\right)$ [Childs et al., 2003; Snyder and Hampton, 2003]. This basic clinoform structure is typical for rivers discharging sediment into still water, with coarse bed load material deposited as a lag in the topset section, sand building the prograding foreset deposits, and suspended load silt, clay, and fine sand in the bottomset beds. Figure 5 shows these grain-size relationships clearly, 


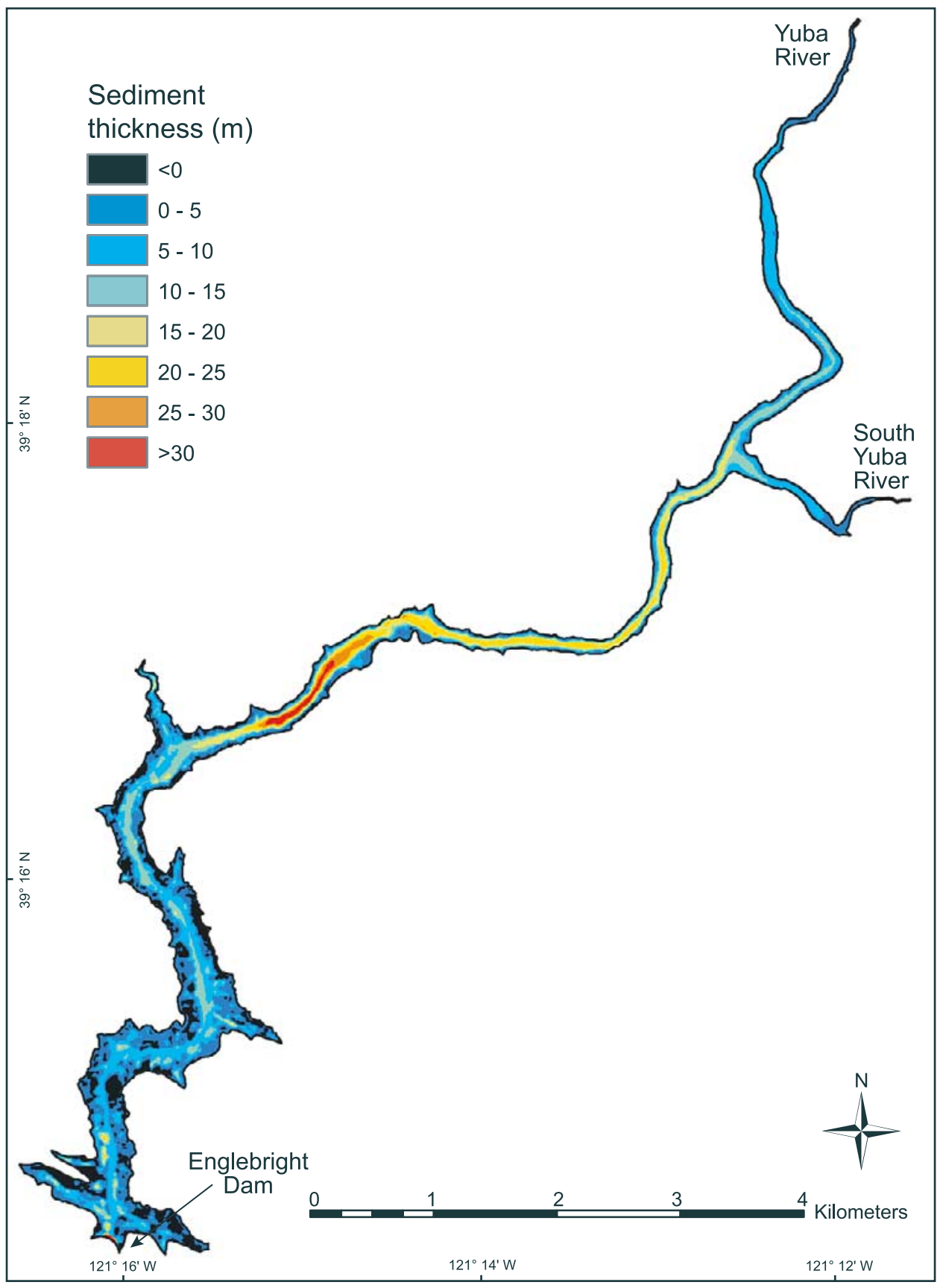

Figure 3. Map of sediment thickness in Englebright Lake [modified from Childs et al., 2003]. Areas with net erosion are shown in black. The volume contained in these areas is $4.5 \%$ of the total and may reflect real erosion or minor inaccuracies in the predam and reservoir floor surfaces [Childs et al., 2003]. Color figures of these surfaces are available from Childs et al. [2003].

with coarse sediment overlying earlier fine bottomset beds in the upstream half of the reservoir. Detailed stratigraphic columns of each of the boreholes are shown in Snyder et al. [2004b]. Here we briefly describe the overall reservoir sedimentary architecture.

[15] The downstream, bottomset part of the reservoir (from the dam to the toe of the delta front; sites 1 and 6 (Figures 4 and 5)) contains deposits up to $\sim 10 \mathrm{~m}$ thick, and is dominated by silt and clay with some fine sand (median grain size, $\mathrm{D}_{50} 0.007-0.04 \mathrm{~mm}$ ) [Snyder et al., 2004a]. The material is layered at widely varying scales, from thin $(\sim 1 \mathrm{~mm})$ clay and silt laminae to thick $(\sim 1 \mathrm{~m})$ massive silt and fine sand units. Organic-rich layers up to $1 \mathrm{~cm}$ thick are interspersed throughout the deposits. The upstream part of the reservoir (sites 4, 7, 9, 8 and 2, and both unsurveyed branches (Figure 4)) contains deposits up to $\sim 35 \mathrm{~m}$ thick and has a more complicated structure than the fine-grained downstream section (Figure 5). The basal section is dominated by silt, clay and fine sand with layers $1 \mathrm{~mm}$ to tens of $\mathrm{cm}$ thick, similar to material seen in the downstream part of 
- Grab samples (April 2002)

O Deep coring sites (May-June 2002)

- Shallow coring sites (October 2002)

ธ Bed material pebble counts

7 Deep coring site and/or region used for reservoir calculations

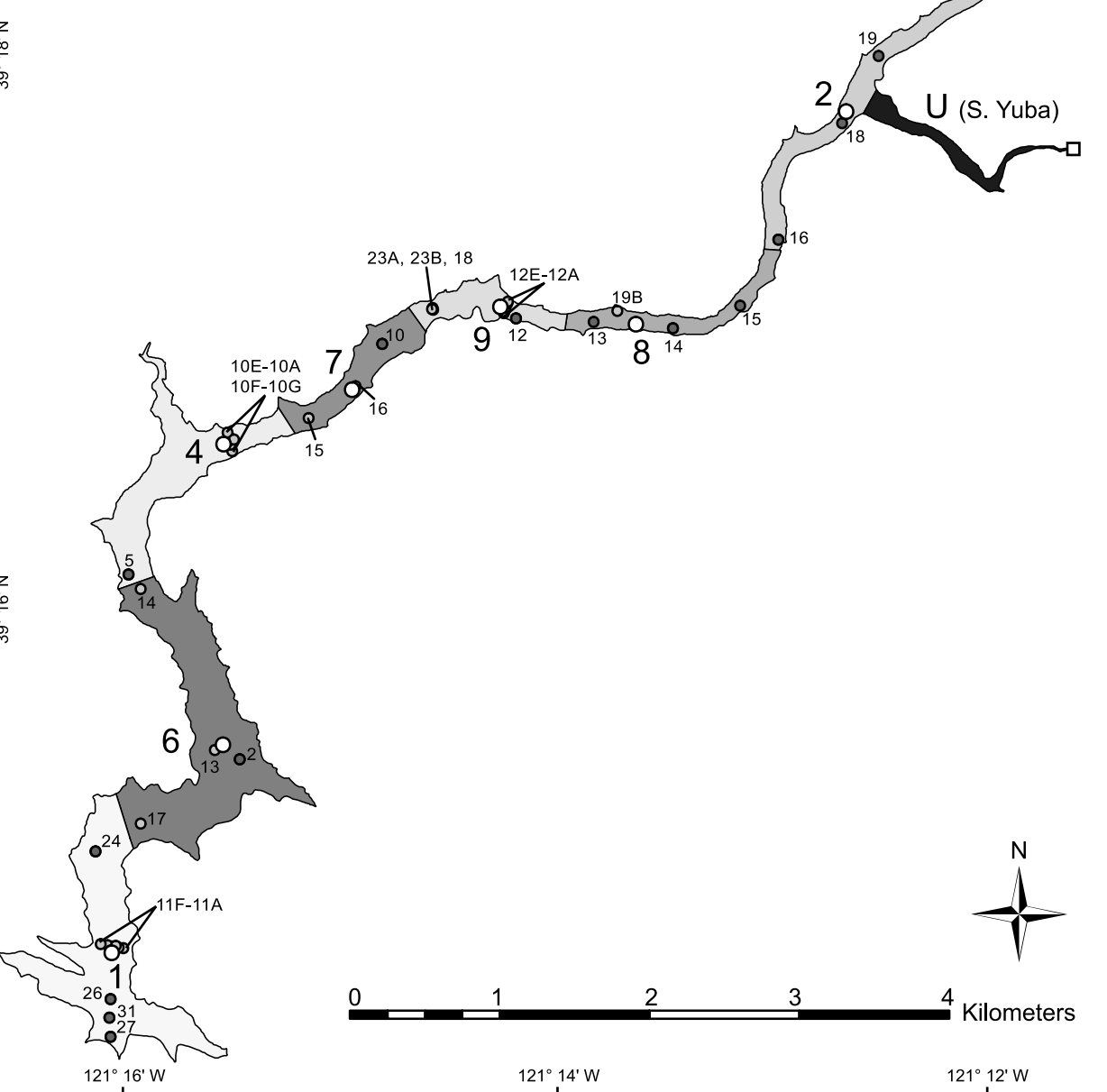

Figure 4. Location of sediment samples taken in Englebright Lake during 2002. Site numbering is in the order of field sampling and remains this way to be consistent with other publications. Also shown are the eight regions used for the reservoir volume and mass calculations. The regions are labeled by their corresponding deep coring site number. The farthest upstream parts of the reservoir (labeled region U) were too shallow for bathymetric surveying [Childs et al., 2003].

the reservoir. Over the scale of many layers $(\sim 2-5 \mathrm{~m})$, the lower sediment generally coarsens upward, as would be expected for the change from bottomset to foreset deposition (Figure 5). Overlying the basal fine-grained units is material dominated by sand and gravel, with some finegrained beds interspersed; $\mathrm{D}_{50}$ ranges from $0.01 \mathrm{~mm}$ to $>2 \mathrm{~mm}$. The coarsest units recovered are from the middle of the profiles at sites 9 and 8 . Thicknesses of individual layers vary from a few centimeters in the finer units to a few meters in the coarser units. Massive layers dominated by organic material (leaves, needles, woody debris) from $<1$ to $\sim 70 \mathrm{~cm}$ thick, are common throughout the upstream section.

\section{Extrapolation of Reservoir Sediment Properties}

[16] We used the composite vertical sediment sections (Figure 5) to quantify the bulk properties of the volume of sediment contained in each region of the reservoir 
Table 1. Site-Averaged Information for the May-June 2002 Deep Coring Campaign

\begin{tabular}{|c|c|c|c|c|c|c|c|c|}
\hline $\begin{array}{l}\text { Deep Coring } \\
\text { Site }^{\mathrm{a}}\end{array}$ & $\begin{array}{l}\text { Latitude } \\
\text { (WGS84) }\end{array}$ & $\begin{array}{l}\text { Longitude } \\
\text { (WGS84) }\end{array}$ & $\begin{array}{l}\text { Top of Cored } \\
\text { Interval, }{ }^{\mathrm{b}} \mathrm{m}\end{array}$ & $\begin{array}{l}\text { Bottom of Cored } \\
\text { Interval, }{ }^{\mathrm{c}} \mathrm{m}\end{array}$ & $\begin{array}{c}\text { Recovery, } \\
\%\end{array}$ & $\begin{array}{l}\text { Number of } \\
\text { Boreholes }\end{array}$ & $\begin{array}{c}\text { Number of } \\
\text { Complete Intervals } \\
\text { Recovered }^{\mathrm{d}}\end{array}$ & $\begin{array}{c}\text { Number of } \\
\text { Composite Series } \\
\text { Subsamples }\end{array}$ \\
\hline 1 & 39.24541 & -121.26868 & 99.25 & 92.92 & 78.7 & 4 & 4 & 23 \\
\hline 6 & 39.25781 & -121.25974 & 109.23 & 102.32 & 83.4 & 6 & 5 & 15 \\
\hline 4 & 39.27595 & -121.25928 & 126.26 & 110.78 & 87.7 & 4 & 4 & 34 \\
\hline 7 & 39.27905 & -121.24925 & 146.37 & 114.45 & 95.3 & 4 & 2 & 68 \\
\hline 9 & 39.28387 & -121.23757 & 150.01 & 126.35 & 86.0 & 3 & 3 & 39 \\
\hline 8 & 39.28274 & -121.22715 & 149.91 & 126.64 & 86.5 & 7 & 2 & 42 \\
\hline 2 & 39.29522 & -121.21050 & 156.78 & $150.46^{\mathrm{e}}$ & 24.4 & 2 & 0 & 2 \\
\hline
\end{tabular}

${ }^{\text {a }}$ Sites in order from downstream to upstream.

${ }^{\mathrm{b}}$ Approximately equal to the mean elevation of the reservoir floor.

${ }^{\mathrm{c}}$ Mean value of the prereservoir surface for all boreholes where the surface was reached

${ }^{\mathrm{d}}$ Number of boreholes where both the top and bottom of the reservoir sediments were recovered.

${ }^{\mathrm{e}}$ Prereservoir surface not reached at site 2. See Childs et al. [2003] and Snyder et al. [2004b] for more information.

(Figure 4). Because these subsamples were taken on intervals based on stratigraphy, each one can be considered a layer. We calculated the average dry bulk density of each layer from multisensor-core-logger and moisture content data [Snyder et al., 2004b], using an empirical calibration presented below. We found the grain size and organic content from laboratory analyses of the subsamples. For all of the calculations the properties of each layer were treated individually; all region-wide quantities are weighted by layer thickness, density, and organic content. Such an approach is important because various sediment properties are likely to be correlated [Verstraeten and Poesen, 2001].

[17] Calculation of the physical properties of the reservoir sediment based on cored material requires a reasonable approach to extrapolating from a one-dimensional vertical sediment section to a three-dimensional volume of sediment within the lake deposit (Figures 4 and 5). This is especially true in the case of a reservoir deposit in a narrow, V-shaped canyon because the lower part of each borehole represents a smaller overall portion than the upper part. This extrapolation can be accomplished based on a conceptual or numerical stratigraphic model provided that it can be verified with data on the three-dimensional distribution of the sedimentary layers, from either dense borehole spacing (so that each borehole only represents a small volume of sediment), or high-resolution stratigraphic mapping using subbottom imaging methods. In the case of Englebright Lake, the high cost (financial and temporal) of deep coring limited collection to 7 sites (Figure 4), located along the predam river thalweg. Furthermore, several seismic reflection surveys were unable to image the reservoir sediments [Childs et al., 2003]. Therefore we chose to use two simple extrapolation schemes based on differing sedimentation styles to convert from a vertical sediment profile to an entire volume, similar to the approach of Gould [1960] in Lake Mead.

\subsection{Variable Layer Thickness Method}

[18] Our first extrapolation method assumes that the vertical distribution of sediment in each composite set of subsamples is representative of all points in the region, i.e., that the relative thickness of each layer compared to the total column remains constant throughout the region. This computationally simple approach was essentially used by Gould [1960], although that study differs from this one because it was based on gravity cores that did not penetrate the entire sedimentary section. In process terms, this is analogous to an assumption that the reservoir filled by draping of sedimentary layers, with very thin layers depos-

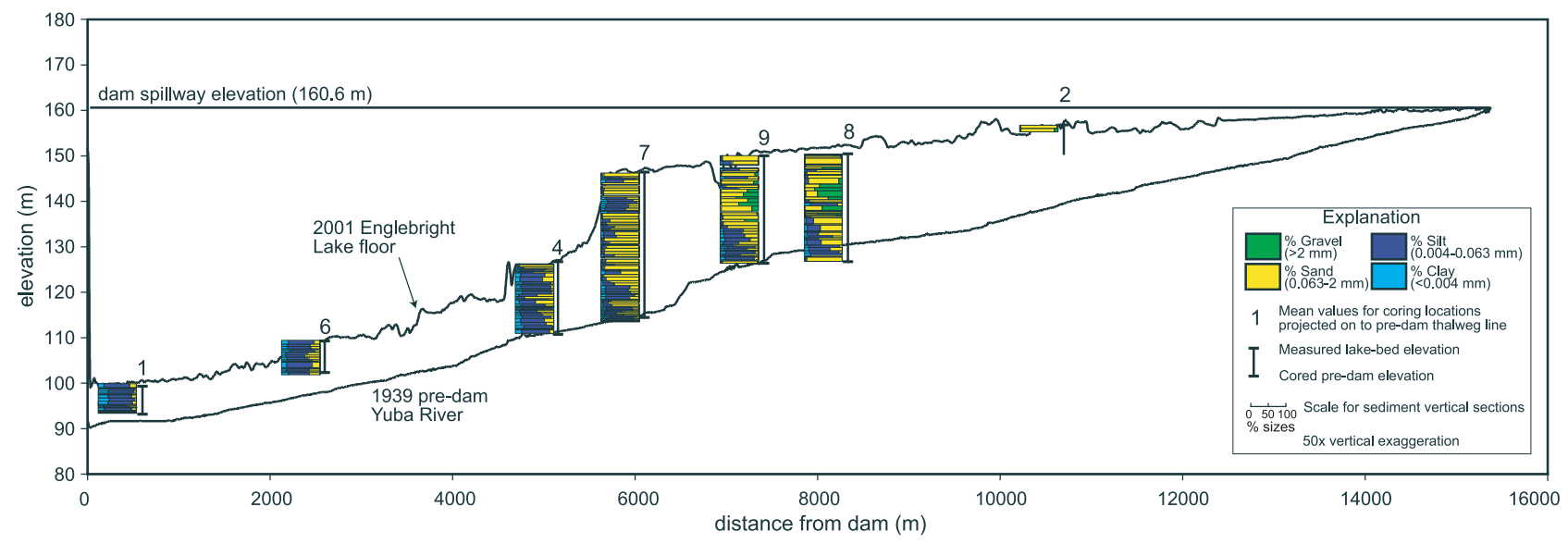

Figure 5. Longitudinal cross section of Englebright Lake [modified from Snyder and Hampton, 2003]. Prereservoir Yuba River topography is from 1939 topographic maps (U.S. Army Corps of Engineers), and 2001 bathymetry is from an acoustic survey [Childs et al., 2003]. Grain-size sections (composite series subsamples) are labeled with deep coring site numbers (Figure 4). Details of the grain-size distribution analysis and results are presented by Snyder et al. [2004a]. 


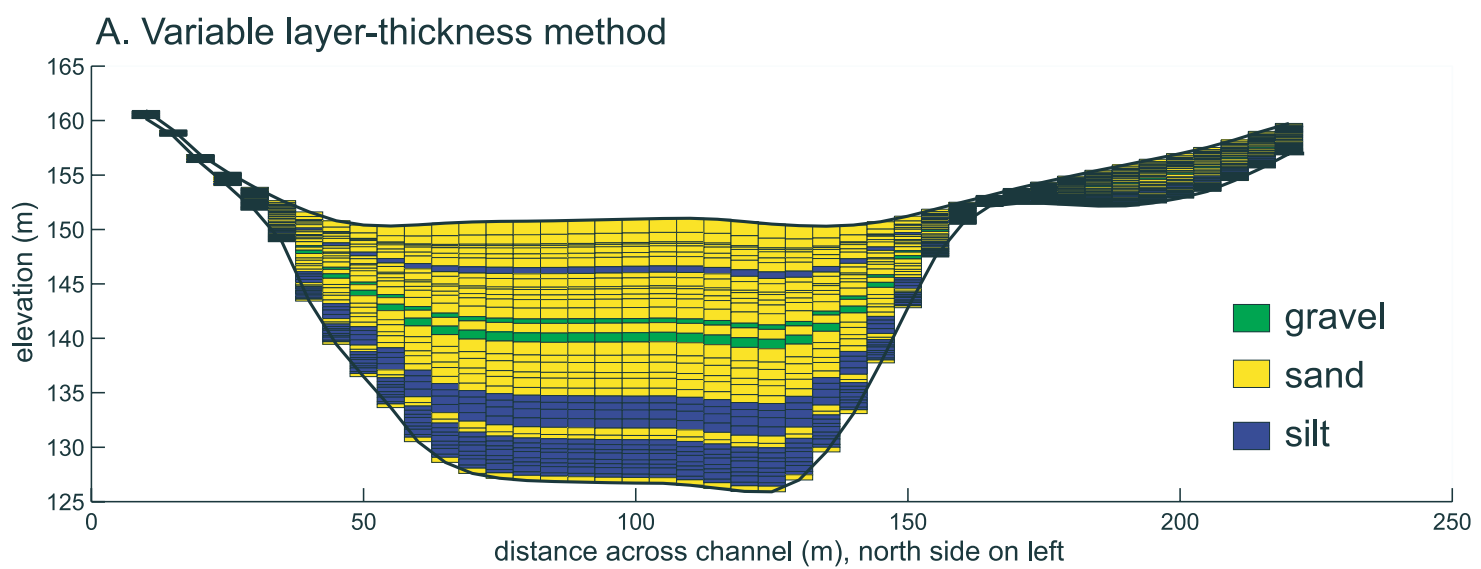

B. Constant layer-thickness method

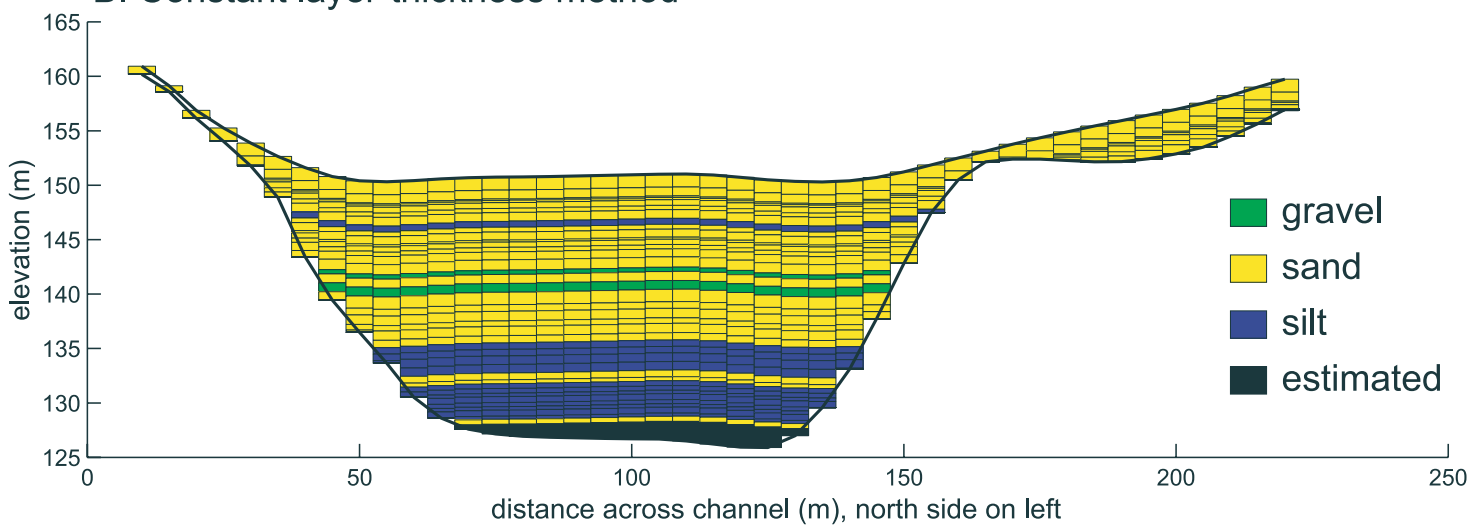

Figure 6. Examples of reservoir sediment extrapolation methods. (a) All layers are found throughout the reservoir deposit, with thickness proportional to total sediment thickness. Note that layers are extremely thin near the sides of the reservoir. (b) Layers are assumed to be parallel to the reservoir floor surface, with constant thickness.

ited on the sides during each phase of deposition, and thick layers deposited in the center (Figure 6a). This style of infilling is probably most appropriate to situations where the reservoir fills with sediment settling out of suspension from a well-mixed water column. In this method, we simply weight each layer by its thickness, density and organic content, and use these to calculate average values for the entire vertical sediment section. These vertically averaged values are then used to calculate quantities for the volume represented by the sediment section.

\subsection{Constant Layer Thickness Method}

[19] Our second extrapolation method is to place the vertical sediment section in the context of a transverse reservoir cross section, with the sedimentary layers deposited parallel to the lake floor surface. Implicit in this approach is an assumption that the reservoir fills from the bottom up, with the oldest sedimentary layers only found in the deepest part of the reservoir (Figure 6b). This style of infilling is most consistent with deposition of material transported along the bed of the reservoir, either as fluvial bed load or as turbidity currents. In this method, we hang the vertical sediment sections from the lake floor along a transverse cross section, and assume that layer thickness does not change. At each 5-m-wide column along the cross section, weighted average quantities of density, organic content, and grain size are calculated. In a few places, the thickness of parts of the cross section exceeds the total thickness of the composite vertical section. In these cases, the bottom material is assumed to be represented by a thickness-weighted average of the lowermost three subsamples.

\subsection{Lateral Variation in Grain Size}

[20] Neither of the methods for extrapolating a composite borehole section (sampled near the channel thalweg) to the entire transverse cross section include lateral changes in grain size. Fining toward the channel margins may be present in some areas because near-bank roughness reduces velocity and thus sediment transport capacity, but we expect that the amount should not have much impact on the extrapolation techniques used here. In the discussion section (below), we evaluate this expectation using data from the shallow coring campaign.

\subsection{Minimally Sampled Parts of the Reservoir}

[21] The upstream part of the reservoir (regions 2 and $U$ (Figure 4)) was cored only minimally (Table 1). This undersampling was the result of three factors. First, the coarse-grained, uncohesive nature of these sediments (sand 
Table 2. Comparison of Wet Bulk Density $\left(\rho_{\mathrm{w}}\right)$ Data Results ${ }^{\mathrm{a}}$

\begin{tabular}{|c|c|c|c|}
\hline Site & $\begin{array}{l}\text { Site Mean and Standard } \\
\text { Deviation }^{\mathrm{b}}\end{array}$ & $\begin{array}{c}\text { Composite Series Mean } \\
\text { (Variable Layer Thickness Method) }^{\mathrm{c}}\end{array}$ & $\begin{array}{c}\text { Composite Series Mean } \\
{\text { (Constant Layer Thickness Method })^{\mathrm{c}}}^{\mathrm{c}}\end{array}$ \\
\hline 1 & $1.379 \pm 0.114$ & 1.374 & 1.378 \\
\hline 6 & $1.397 \pm 0.118$ & 1.399 & 1.402 \\
\hline 4 & $1.450 \pm 0.193$ & 1.468 & 1.451 \\
\hline 7 & $1.645 \pm 0.270$ & 1.635 & 1.634 \\
\hline 9 & $1.799 \pm 0.273$ & 1.831 & 1.838 \\
\hline 8 & $1.825 \pm 0.261$ & 1.828 & 1.854 \\
\hline 2 & $2.068 \pm 0.056$ & 2.068 & 2.068 \\
\hline
\end{tabular}

and gravel) meant that recovery in core liners was difficult or impossible. Second, the coarse-grained material (including at least cobbles) was difficult to penetrate. Third, the shallow water depths and swift river currents upstream of coring site 2 (in both branches of the reservoir (Figure 4)) precluded access with the coring rig. As a result, calculations of the properties of sediment in the reservoir upstream of region 8 are poorly constrained and treated separately in the reservoir mass and grain-size calculations. To gain some insight to the nature of the material contained in the upstream part of the reservoir, we use the minimal coring and sampling that was accomplished, augmented with comparisons to better recovered deposits from downstream locations [Gould, 1960].

\section{Results and Interpretations}

\subsection{Sediment Density and Moisture Content}

[22] To calculate sediment quantities and loads to Englebright Lake, estimates of the dry bulk density were necessary. Wet bulk density $\left(\rho_{\mathrm{w}}\right)$ of the cored material was measured at $1 \mathrm{~cm}$ intervals in the core sections using a multisensor logger [Snyder et al., 2004b]. This measurement is only an approximation of the "true" bulk density of the in-place reservoir sediment, because of changes caused by coring and storage, such as gas expansion (discussed below) or water leakage. The mean values of wet bulk density for each site calculated from a simple average of all multisensor logger data compare well with the site means based on the composite series of subsamples using either of the two extrapolation techniques outlined above (Table 2). The wet and dry mass of material $\left(\mathrm{m}_{\mathrm{w}}\right.$ and $\left.\mathrm{m}_{\mathrm{d}}\right)$ was measured at 1 or 2 points in each core section (up to $1.5 \mathrm{~m}$ long). Assuming no change in volume, the percent dry weight $\left(\mathrm{m}_{\mathrm{d}} / \mathrm{m}_{\mathrm{w}}\right)$ can be used to estimate dry bulk density $\left(\rho_{\mathrm{d}}\right)$, via the relation

$$
\rho_{\mathrm{d}}=\frac{\mathrm{m}_{\mathrm{d}}}{\mathrm{m}_{\mathrm{w}}} \rho_{\mathrm{w}}
$$

Figure 7 compares measured values of $\rho_{\mathrm{w}}$ with calculated values of $\rho_{\mathrm{d}}$ at all of the points where both moisture content and wet bulk density were measured [Snyder et al., 2004b]. The empirical linear best fit to these data $\left(\rho_{\mathrm{d}}=1.29 \rho_{\mathrm{w}}-\right.$ $1.02)$ shows a strong correlation $\left(\mathrm{R}^{2}=0.96\right)$; we used this general relation to calculate $\rho_{\mathrm{d}}$ from values of $\rho_{\mathrm{w}}$ for core intervals without moisture content analyses. The relationship between $\rho_{\mathrm{d}}$ and $\rho_{\mathrm{w}}$ depends on a variety of factors including degree of saturation, grain size, and porosity, however, the strong correlation in the linear regression (Figure 7) shows that this simple approach is reasonable for the range of sediments sampled in Englebright Lake.

\subsection{Calculations of Reservoir Sediment Quantities and Physical Properties}

4.2.1. Downstream Reservoir Mass of Sediment

[23] Using the dry bulk density values calculated as above, the two extrapolation methods yield almost identical $( \pm 0.5 \%)$ estimates of the total mass of the downstream reservoir deposit: 17.1 and $17.2 \times 10^{6}$ metric tons $(t)$ for the variable and constant layer thickness methods, respectively (Tables $3 \mathrm{a}$ and $3 \mathrm{~b}$ ). Of this material, 3.8 to $3.9 \%$ was lost on ignition and therefore organic, so the total mass of inorganic sediment in the downstream reservoir is about $16.5 \times 10^{6} \mathrm{t}$.

4.2.2. Downstream Reservoir Grain Size of Sediment

[24] The two extrapolation methods differ more in the reservoir-average grain-size estimates. With the variable layer thickness method (which gives equal weight to the top and bottom vertical grain-size profiles) the downstream

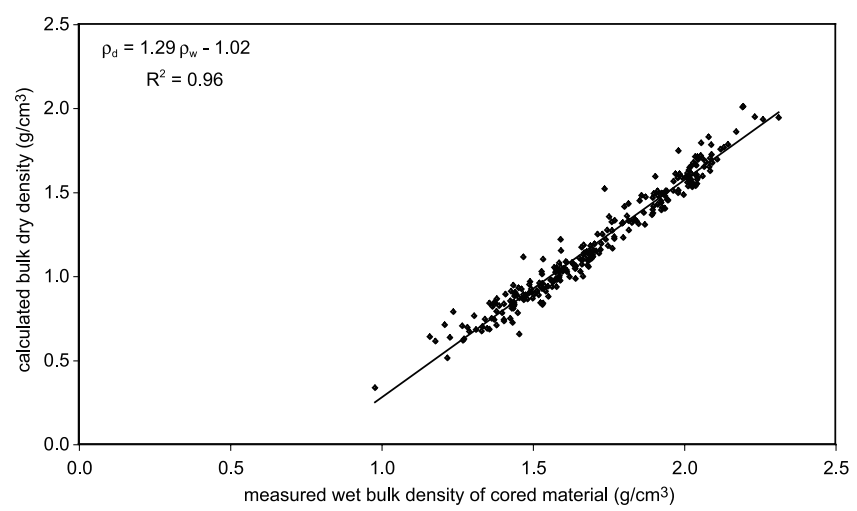

Figure 7. Comparison of measured wet bulk density of cored material $\left(\rho_{\mathrm{w}}\right)$ at intervals where moisture content samples were taken, with calculated dry bulk density $\left(\rho_{\mathrm{d}}\right)$ via equation (1). The original data and analysis methods are presented by Snyder et al. [2004b]. The best-fit line and an equation of a linear regression to the data are shown. This empirical relation was used to calculate $\rho_{\mathrm{d}}$ for intervals where moisture content samples were not taken. In general, the range in bulk density seen in the reservoir correlates with grain size [e.g., Verstraeten and Poesen, 2001]. 
Table 3a. Englebright Lake Sediment Quantities, Calculated Using the Variable Layer Thickness Extrapolation Method ${ }^{\mathrm{a}}$

\begin{tabular}{|c|c|c|c|c|c|c|c|c|c|c|c|}
\hline Region & $\begin{array}{l}\text { Volume, } \\
\times 10^{6} \mathrm{~m}^{3} \\
\end{array}$ & $\rho_{\mathrm{w}}, \mathrm{g} / \mathrm{cm}^{3}$ & $\rho_{\mathrm{d}}, \mathrm{g} / \mathrm{cm}^{3}$ & $\begin{array}{c}\text { Total Mass, } \\
\times 10^{6} \mathrm{t}\end{array}$ & $\%$ LOI & $\%$ Clay & $\%$ Silt & $\%$ Sand & $\%$ Gravel & $\begin{array}{c}\text { Sediment Mass, } \\
\times 10^{6} \mathrm{t}\end{array}$ & $\mathrm{D}_{50}, \mathrm{~mm}$ \\
\hline \multicolumn{12}{|c|}{ Downstream Reservoir } \\
\hline 1 & 2.4 & 1.37 & 0.76 & 1.8 & 5.0 & 22.7 & 66.5 & 10.8 & 0.0 & 1.7 & 0.008 \\
\hline 6 & 3.4 & 1.40 & 0.79 & 2.7 & 5.8 & 16.2 & 61.9 & 21.9 & 0.1 & 2.5 & 0.025 \\
\hline 4 & 2.9 & 1.47 & 0.88 & 2.6 & 6.2 & 13.7 & 57.6 & 28.7 & 0.0 & 2.4 & 0.023 \\
\hline 7 & 3.5 & 1.63 & 1.09 & 3.8 & 3.1 & 7.5 & 31.8 & 60.5 & 0.2 & 3.7 & 0.110 \\
\hline 9 & 2.3 & 1.83 & 1.35 & 3.1 & 2.2 & 5.1 & 25.1 & 60.6 & 9.2 & 3.0 & 0.192 \\
\hline 8 & 2.4 & 1.83 & 1.35 & 3.2 & 2.2 & 4.3 & 21.8 & 59.1 & 14.8 & 3.1 & 0.245 \\
\hline Subtotal & 16.9 & 1.57 & 1.02 & 17.1 & 3.9 & 10.3 & 40.8 & 44.4 & 4.5 & 16.5 & 0.112 \\
\hline \multicolumn{12}{|c|}{ Upstream Reservoir } \\
\hline 2 & 3.5 & 2.07 & 1.66 & 5.7 & 1.9 & 1.0 & 4.0 & 65.0 & 30.0 & 5.6 & 0.486 \\
\hline U-Yuba & 1.0 & 2.07 & 1.66 & 1.6 & 1.9 & 0.0 & 0.0 & 1.0 & 99.0 & 1.6 & na \\
\hline U-SYuba & 0.6 & 2.07 & 1.66 & 1.0 & 1.9 & 0.0 & 0.0 & 28.0 & 72.0 & 1.0 & na \\
\hline Subtotal & 5.0 & 2.07 & 1.66 & 8.3 & 1.9 & 0.7 & 2.8 & 48.4 & 48.2 & 8.2 & na \\
\hline Total or mean & 21.9 & 1.69 & 1.16 & 25.5 & 3.2 & 7.1 & 28.1 & 45.7 & 19.0 & 24.7 & na \\
\hline
\end{tabular}

ana, no estimate made.

reservoir deposit contains $48.9 \%$ sand and gravel, whereas the constant layer thickness method (which emphasizes the top of the profile) gives an estimate of 54.6\% sand and gravel. The two estimates differ primarily in the coarseningupward part of the reservoir (sites 4, 7, 9, and 8). By weighting the top part of the section, the constant layer thickness method yields coarser averages in this part of the reservoir. Similarly, the median grain size $\left(D_{50}\right)$ of the downstream reservoir deposit differs from 0.112 to 0.184 $\mathrm{mm}$ using the two extrapolation techniques. Regardless of extrapolation method, the downstream reservoir deposit is dominated by fine sand, but the grain size of the deposit shows considerable variation both vertically and longitudinally, as discussed below.

\subsubsection{Upstream Reservoir Sediment Properties}

[25] The sediment properties of the upstream part of the reservoir deposit (regions 2 and U (Figure 4)) are poorly constrained. Because of logistical limitations, we only have a small number of surficial sediment samples in this part of the reservoir, and a single, incomplete vertical section of cored sediments from site 2 . As a result we estimate the density, organic content, and grain-size distribution of the upstream reservoir based on limited sampling and inferen- ces drawn by projecting trends from the downstream part of the reservoir.

[26] At site 2 (Figures 4 and 8), we recovered one core that sampled the top $1.46 \mathrm{~m}$ of the sediment section [Snyder et al., 2004a, 2004b]. The core was subsampled in 2 intervals of 72 and $74 \mathrm{~cm}$. The median grain size of the core is $0.486 \mathrm{~mm}$, and the composition is $0.7 \%$ clay, $2.2 \%$ silt, $90.4 \%$ sand, and $6.7 \%$ gravel. Grab samples 16,18 , and 19 are also from region 2 (Figures 4 and 8). The average of these three samples yields a $\mathrm{D}_{50}$ of $0.287 \mathrm{~mm}$, and $2.4 \%$ clay, $11.0 \%$ silt, $86.2 \%$ sand, and $0.4 \%$ gravel. It would be tempting simply to extrapolate the core distribution to all of region 2 , but there are several reasons to believe that the grain-size distribution from these surficial samples is not representative of the material at depth. First, the reservoir below site 2 exhibits a downstream-fining trend, particularly in gravel content (Figure 5). We should therefore expect region 2 to have a higher percentage of gravel than region 8 . Second, during coring we did penetrate deeper than the top $1.46 \mathrm{~m}$, and had recovery problems because of layers of coarser material (pebbles and cobbles), a few particles of which were recovered. Third, while the delta deposit (as seen in sites 7,9 and 8) does generally coarsen upward, the

Table 3b. Englebright Lake Sediment Quantities, Calculated Using the Constant Layer Thickness Extrapolation Method ${ }^{\mathrm{a}}$

\begin{tabular}{|c|c|c|c|c|c|c|c|c|c|c|c|}
\hline Region & $\begin{array}{l}\text { Volume, } \\
\times 10^{6} \mathrm{~m}^{3}\end{array}$ & $\rho_{\mathrm{w}}, \mathrm{g} / \mathrm{cm}^{3}$ & $\rho_{\mathrm{d}}, \mathrm{g} / \mathrm{cm}^{3}$ & $\begin{array}{l}\text { Total Mass, } \\
\quad \times 10^{6} \mathrm{t}\end{array}$ & $\%$ LOI & $\%$ Clay & $\%$ Silt & $\%$ Sand & $\%$ Gravel & $\begin{array}{l}\text { Sediment Mass, } \\
\times 10^{6} \mathrm{t}\end{array}$ & $\mathrm{D}_{50}, \mathrm{~mm}$ \\
\hline \multicolumn{12}{|c|}{ Downstream Reservoir } \\
\hline 1 & 2.4 & 1.38 & 0.76 & 1.9 & 4.9 & 22.4 & 67.9 & 9.7 & 0.0 & 1.8 & 0.010 \\
\hline 6 & 3.4 & 1.40 & 0.80 & 2.7 & 5.9 & 16.5 & 61.9 & 21.5 & 0.1 & 2.6 & 0.020 \\
\hline 4 & 2.9 & 1.45 & 0.86 & 2.5 & 6.3 & 13.0 & 55.3 & 31.7 & 0.0 & 2.3 & 0.027 \\
\hline 7 & 3.5 & 1.63 & 1.10 & 3.8 & 3.0 & 6.1 & 25.3 & 68.4 & 0.3 & 3.7 & 0.165 \\
\hline 9 & 2.3 & 1.84 & 1.36 & 3.1 & 2.1 & 3.8 & 18.1 & 67.2 & 10.9 & 3.0 & 0.325 \\
\hline 8 & 2.4 & 1.85 & 1.38 & 3.3 & 2.0 & 2.7 & 13.2 & 63.8 & 20.3 & 3.2 & 0.426 \\
\hline Subtotal & 16.9 & 1.58 & 1.02 & 17.2 & 3.8 & 9.3 & 36.0 & 48.6 & 6.0 & 16.6 & 0.184 \\
\hline \multicolumn{12}{|c|}{ Upstream Reservoir } \\
\hline 2 & 3.5 & 2.07 & 1.66 & 5.7 & 1.9 & 1.0 & 4.0 & 65.0 & 30.0 & 5.6 & 0.480 \\
\hline U-Yuba & 1.0 & 2.07 & 1.66 & 1.6 & 1.9 & 0.0 & 0.0 & 1.0 & 99.0 & 1.6 & na \\
\hline U-SYuba & 0.6 & 2.07 & 1.66 & 1.0 & 1.9 & 0.0 & 0.0 & 28.0 & 72.0 & 1.0 & na \\
\hline Subtotal & 5.0 & 2.07 & 1.66 & 8.3 & 1.9 & 0.7 & 2.8 & 48.4 & 48.2 & 8.2 & na \\
\hline Total or mean & 21.9 & 1.69 & 1.17 & 25.6 & 3.2 & 6.5 & 25.0 & 48.5 & 20.0 & 24.8 & na \\
\hline
\end{tabular}

${ }^{\text {a }}$ na, no estimate made. 


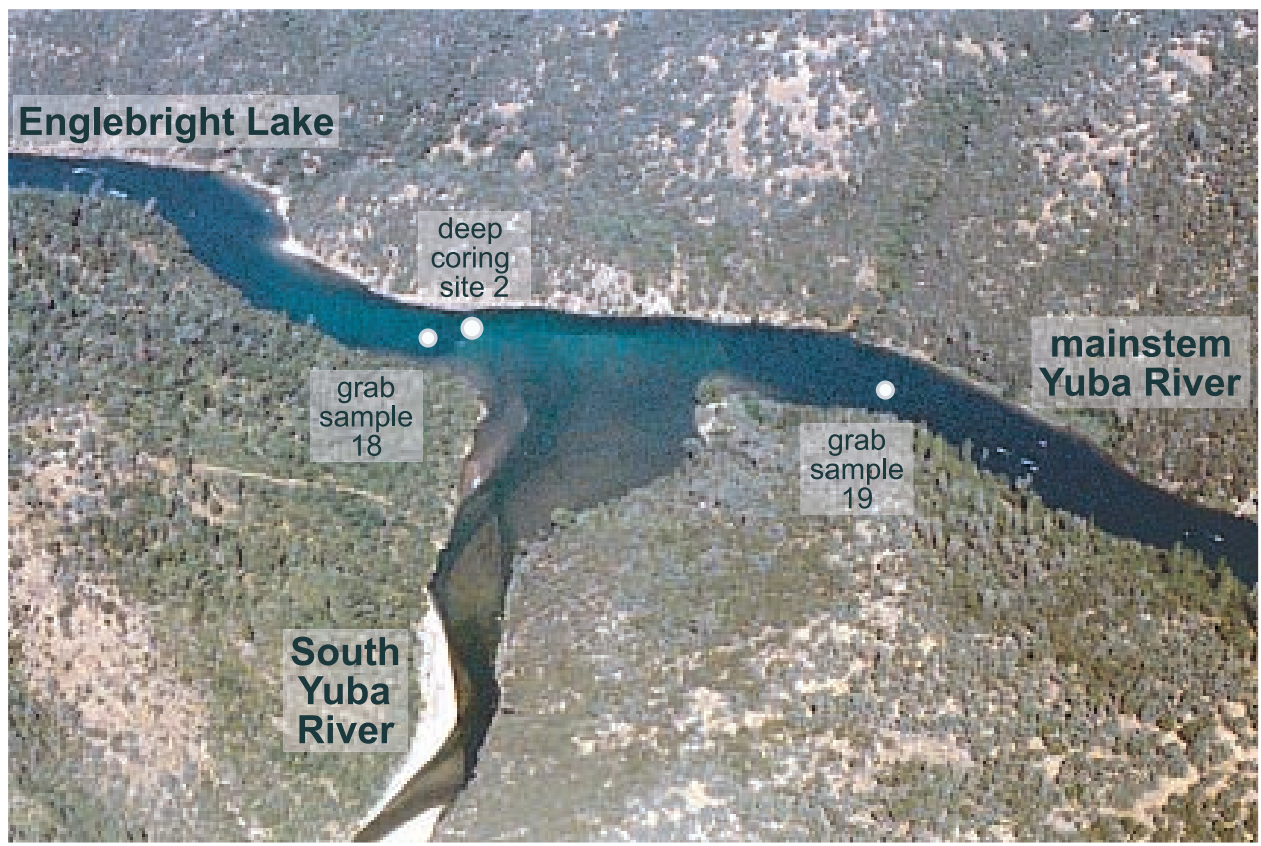

Figure 8. Oblique aerial photograph of the confluence of the south and mainstem branches of the Yuba River at the upstream end of Englebright Lake on 11 July 2002. The view is to the northwest. The positions of two grab samples taken in April 2002 and deep coring site 2 are marked. Note the extensive sand bar deposits at the mouth of the South Yuba River.

coarsest material is not at the top, but more in the middle (Figure 5). We expect a similar relationship at site 2. So, instead of extrapolating based solely on the top $\sim 1.5 \mathrm{~m}$ of sediment recovered at site 2 , our "best guess" modification of the distribution is to assume that the sand content is about the same as in sites 8 and $9(\sim 65 \%)$, but that the balance is composed almost entirely of gravel $(\sim 30 \%)$ with a small quantity of fine sediments ( $\sim 5 \%$ (Tables $3 a$ and $3 b)$ ).

[27] The situation is even more unconstrained in region U, the unsurveyed part of the reservoir [Childs et al., 2003]. This region undoubtedly contains the coarsest part of the reservoir deposit, as the backwater during normal dam operations (water surface elevation 157-160 m) starts at about site 2 (Figure 4). The only observations made in these areas are a pair of pebble counts $(n=100$ [Wolman, 1954]) to characterize the bed material. One survey was completed on the mainstem river at the Colgate gauging station, and the other just downstream of the Bridgeport Bridge on the South Yuba River. Both of these sites are near the upstream ends of the lake deposits (Figure 4). At the mainstem site, the bed material is $99 \%$ gravel, and $1 \%$ sand, with a $\mathrm{D}_{50}$ of $90.5 \mathrm{~mm}$. At the South Yuba site, the bed is $72 \%$ gravel and $28 \%$ sand, with a $\mathrm{D}_{50}$ of $22.6 \mathrm{~mm}$. These distributions are consistent with qualitative visual observations of the upstream ends of the lake. The coarser sediment in the mainstem is expected because the river downstream of New Bullards Bar Dam is starved of sediment available for transport, and the bed is therefore depleted with respect to sand. Conversely, the South Yuba River transports a large quantity of sand, as evidenced by the active bar seen around site 2, where the South Yuba enters Englebright Lake (Figure 8). For lack of more information, we assume that the particle-size class distributions at the river bed in the two branches of the unsurveyed region are representative of the deposits at depth (we do not estimate $\mathrm{D}_{50}$ ). Because most of the sediment in the upstream part of the reservoir is likely coarse, the larger uncertainty in our grain-size estimations is likely in the relative percentages of sand and gravel, whereas the more broad classifications of coarse sediments $(>0.063 \mathrm{~mm})$ and fine sediments $(<0.063 \mathrm{~mm})$ should be robust.

[28] Estimates of density and organic content for the unsurveyed part of the lake are also necessary. The site 2 core had a depth-averaged dry density $\left(\rho_{\mathrm{d}}\right)$ of $1.66 \mathrm{~g} / \mathrm{cm}^{3}$, and a depth-and-density-averaged loss on ignition of $1.9 \%$. These values continue the general trends of increasing density and decreasing organic content from the regions downstream, and for lack of an alternative we use them to represent all of the upstream part of the reservoir (regions 2 and $U$ ). This value of $\rho_{\mathrm{d}}$ is at the high end of the range of values observed in the reservoir (Figure 7), and it is consistent with the coarse grain size estimated for the region. One might expect that a density estimate based on a surficial core would be low because we ignore compaction, but in sites 9 and 8 the density does not increase with depth, and in fact is lower in the fine-grained basal section. This extrapolation is reasonable given the considerable uncertainties.

\subsubsection{Overall Estimate of Reservoir Sediment Mass and Grain Size}

[29] Tables 3a and 3b summarize our estimate of the total contents of the reservoir deposits. Because density increases and organic content decreases in the upstream direction, the total sedimentary deposit stored in the upstream part of the reservoir represents a larger percentage of the total mass and a smaller percentage of the total volume. The regions contain from $7 \%$ (region 1) to $23 \%$ (region 2) of the total mass of material, with $67 \%$ in the well-characterized down- 
Table 4. Englebright Lake Sedimentation Rates ${ }^{\mathrm{a}}$

\begin{tabular}{|c|c|c|c|c|c|c|c|c|c|c|}
\hline $\begin{array}{c}\text { Layer Thickness } \\
\text { Method }\end{array}$ & $\begin{array}{l}\text { Sediment } \\
\text { Volume, } \\
\times 10^{6} \mathrm{~m}^{3}\end{array}$ & $\begin{array}{l}\text { Total } \\
\text { Mass, } \\
\times 10^{6} \mathrm{t}\end{array}$ & $\begin{array}{l}\text { Sediment } \\
\text { Mass, } \\
\times 10^{6} \mathrm{t}\end{array}$ & $\begin{array}{c}\text { Sand and } \\
\text { Gravel Mass, } \\
\times 10^{6} \mathrm{t}\end{array}$ & $\begin{array}{l}\text { Infilling } \\
\text { Rate, } \\
\times 10^{3} \mathrm{~m}^{3} / \mathrm{yr}\end{array}$ & $\begin{array}{l}\text { Sediment } \\
\text { Load, } \\
\times 10^{3} \mathrm{t} / \mathrm{yr}\end{array}$ & $\begin{array}{l}\text { Sand and } \\
\text { Gravel Load, } \\
\times 10^{3} \mathrm{t} / \mathrm{yr}\end{array}$ & $\begin{array}{c}\text { Sediment Yield } \\
\text { (Yuba River), } \\
\text { t/ } \mathrm{km}^{2} / \mathrm{yr}\end{array}$ & $\begin{array}{l}\text { Sediment Yield } \\
\text { (Middle/South } \\
\text { Yuba), }{ }^{\mathrm{c}} \mathrm{t} / \mathrm{km}^{2} / \mathrm{yr}\end{array}$ & $\begin{array}{c}\text { Lowering } \\
\text { Rate, }, \mathrm{c} \text { ( } \\
\mathrm{mm} / \mathrm{yr}\end{array}$ \\
\hline Variable & 21.9 & 25.5 & 24.6 & 16.0 & 359 & 404 & 263 & 141 & 339 & 0.13 \\
\hline Constant & 21.9 & 25.6 & 24.8 & 17.0 & 359 & 406 & 279 & 141 & 341 & 0.13 \\
\hline
\end{tabular}

stream section (compared to $77 \%$ by volume). The total mass of the deposit is $25.5 \times 10^{6}$ metric tons $(\mathrm{t})$, of which $\sim 24.7 \times 10^{6} \mathrm{t}$ is inorganic sediment. The variable layer thickness extrapolation method yields an overall composition of $65 \%$ sand and gravel and 35\% silt and clay. Because it emphasizes the upper part of the section, the constant layer thickness method predicts $69 \%$ sand and gravel, and $31 \%$ silt and clay. We did not estimate the overall median grain size of the deposit because it would be strongly influenced by the coarse, uncertain upstream regions (2 and $\mathrm{U})$.

\subsection{Rates of Sediment Deposition}

[30] Table 4 shows the average rates of sediment infilling of the reservoir between dam completion (1940) and the bathymetric survey (2001), for the two different extrapolation methods. The mean volumetric infilling rate is $359 \times$ $10^{3} \mathrm{~m}^{3} / \mathrm{yr}$. The mean sediment load that is deposited in the reservoir is $\sim 405 \times 10^{3} \mathrm{t} / \mathrm{yr}$. Estimates of sediment yield (sediment load divided by drainage area) from reservoir sedimentation studies depend on the history of upstream sediment trapping by dams. Therefore we bracket our calculations with two end-member scenarios. The minimum sediment yield estimate $\left(125 \mathrm{~m}^{3} / \mathrm{km}^{2} / \mathrm{yr}\right.$ or $\left.\sim 141 \mathrm{t} / \mathrm{km}^{2} / \mathrm{yr}\right)$ uses the full Yuba River upstream of Englebright Dam $\left(2870 \mathrm{~km}^{2}\right)$, which is certainly an underestimate. The maximum estimate, $\left(301 \mathrm{~m}^{3} / \mathrm{km}^{2} / \mathrm{yr}\right.$ or $\left.\sim 340 \mathrm{t} / \mathrm{km}^{2} / \mathrm{yr}\right)$ uses the reduced area of the watershed not impounded by the New Bullards Bar, Milton, and Lake Spaulding dams $\left(1192 \mathrm{~km}^{2}\right)$, all of which existed in some form prior to 1940 (as discussed above).

\subsection{Interpretation of Rate Calculations}

[31] As expected given the history of hydraulic mining particularly in the South Yuba watershed [Gilbert, 1917], $301 \mathrm{~m}^{3} / \mathrm{km}^{2} / \mathrm{yr}$ is a high sediment yield, but within the range of other northern California reservoirs [Dendy and Champion, 1978]. For instance, surveys of Bullards Bar Reservoir indicate a volumetric sediment yield of $135 \mathrm{~m}^{3} / \mathrm{km}^{2} / \mathrm{yr}$ (1919-1939 [Dendy and Champion, 1978]). Our maximum estimates are probably the most reasonable, because (1) large quantities of sediment must be stored in the upstream reservoirs, and (2) sediment not trapped by these reservoirs is likely to also flow past Englebright Dam. We hypothesize that sediment yield should be decreasing with time in Englebright Lake both due to increasing impoundment and management of the watershed upstream, and the continued reduction of sediment pulse (or pulses) from hydraulic mining [Gilbert, 1917; James, 1993, 1999]. The declining yield hypothesis will be tested through future investigation of the timing of deposition in Englebright Lake using ${ }^{137}$ Cs geochronology. Yuba River sediment yields are discussed more thoroughly by J. A. Curtis et al. (Sediment transport in the upper Yuba River watershed, California, 2001-2003, submitted to U.S. Geological Survey Scientific Investigations Report, 2004); it must be emphasized that not all parts of the watershed are contributing sediment at the same rate, areas that were subjected to hydraulic mining still yield a disproportionate amount [James, 2004]. Given these caveats, assuming an average bedrock density of $2650 \mathrm{~kg} / \mathrm{m}^{3}$ results in a basinwide average lowering rate of $0.13 \mathrm{~mm} / \mathrm{yr}$ based on the reduced drainage area.

\section{Discussion}

\subsection{Uncertainties and Limitations}

[32] The calculations of sedimentation quantities and rates presented in the previous sections represent our best estimates based on the available data; however they are based on a number of extrapolations, approximations, and assumptions. In this section, we discuss the uncertainties and limitations of the analysis, including reservoir trapping efficiency, transverse and longitudinal variability in sediment properties, analytical errors, and extrapolation methodology. The largest source of uncertainty in this study is unquantifiable; we have only limited data in the upstream part of the reservoir. Therefore in this section the emphasis is on nonrandom errors that might cause systematic biases in our estimations of reservoir sediment quantities and properties.

\subsubsection{Reservoir Sediment Trap Efficiency}

[33] Any reservoir will trap only a portion of the sediment load delivered to it; the finest particles travel as wash load and are conveyed through the reservoir and often times past the dam. To compare the rates and quantities of material stored in the reservoir presented here to watershed sediment transport studies requires some estimate of the fraction of the total Yuba River load contained in Englebright Lake. Englebright Dam was built specifically for the purpose of containing sediment, so we might expect it to have relatively high trap efficiency, defined as the ratio of the mass of sediment deposited in the reservoir over the mass of sediment delivered to the upstream end of the reservoir. Trap efficiency is not static; it will change as the reservoir fills with sediment, and with differing reservoir management and hydrologic conditions [Morris and Fan, 1998; Verstraeten and Poesen, 2000]. In particular, trap efficiency is likely to decrease if the water surface elevation in the reservoir is lowered often, providing the opportunity for resuspension and transport of stored sediments. Englebright 
Lake was drawn down $\sim 20$ m each summer and autumn for irrigation prior to the completion of New Bullards Bar Dam in 1970 .

[34] The most commonly used means for calculating reservoir trap efficiency are the empirical relations of Brown [1943], Brune [1953], and Heinemann [1981] (reviewed by Verstraeten and Poesen [2000]), based on the ratio of reservoir capacity to annual water inflow, known as the Brune ratio. This approach is attractive because the dependent variables are easily measured. For Englebright Lake the average annual inflow is $2.2 \times 10^{9} \mathrm{~m}^{3} / \mathrm{yr}\left(70 \mathrm{~m}^{3} / \mathrm{s}\right)$ and the original reservoir capacity was $8.9 \times 10^{7} \mathrm{~m}^{3}$, which yields a Brune ratio of $4.0 \times 10^{-2} \mathrm{~s}^{-1}$. Depending on which empirical curve is used, this predicts a trap efficiency of $75 \%$ to $99 \%$. This wide range in trap efficiency is a reminder that reservoir trap efficiency depends on a much more complicated set of variables than the Brune ratio, such as geometry of the reservoir and its outflow, management style, and incoming sediment concentration and grain-size distribution.

[35] The best way to analyze trap efficiency for a given reservoir is to use incoming and outgoing total sediment load data. Unfortunately, these data are rarely collected for long periods of time. During part of the UYRSP study period (water years 2001-2002), suspended sediment samples were taken at three U.S. Geological Survey gauges upstream of Englebright Lake (YC, MYSJ, SYJB), and at the gauging station just below the dam (YE (Figure 1)). These data were used to estimate daily and monthly suspended sediment loads into and out of Englebright Lake [Rockwell et al., 2002; Smithson et al., 2003]. Water years 2001 and 2002 included no significant (i.e., >2 year recurrence interval) flood events, and average or belowaverage annual inflow, so these data are probably not representative of long-term trends in the reservoir. By comparing loads into Englebright Lake at the two upstream gauges closest to Englebright Lake (YC and SYJB (Figure 1)) to the load at the Englebright Dam gauging station (YE), we can make a rough, direct estimate of trap efficiency (assuming minimal additional contribution between the gauges and the dam). We focus this analysis on the months (December-March) during which time significant sediment transport occurs on the Middle Yuba and South Yuba rivers above the reaches directly affected by dam operations. The average suspended sediment trap efficiency during this period was $58 \%$. Undoubtedly all of the bed load in transport is trapped as well, though not measured, thereby increasing overall trap efficiency. The large quantity of coarse sand and gravel stored in the upstream part of the reservoir indicates that the bed load contribution must be significant (i.e., $>20 \%$ of the total mass (Figure 5, Tables 3a and 3b)).

[36] The sediment load calculations herein reflect only the sediment trapped in the reservoir, and omit the material that remains in suspension through the entire reservoir. Empirical models calibrated to other systems predict that $75 \%$ to $99 \%$ of the total sediment delivered to Englebright Lake by the Yuba River should be deposited behind the dam. The sediment exported from the reservoir at present is dominated by fine-grained (clay and silt) wash load material, whereas the coarse material in transport is deposited in the upstream part of the reservoir. In the future, when the delta front progrades to a position closer to the dam, sand and gravel export may begin. A more sophisticated study of trap efficiency in Englebright Lake is warranted.

\subsubsection{Longitudinal and Transverse Variability in Grain Size}

[37] The analysis of bulk reservoir sedimentary properties presented here depends on the assumption that the coring sites are reasonable representations of the surrounding material, both in the longitudinal and transverse directions. To some extent we can make use of the greater spatial sampling density provided by the grab sampling and shallow coring campaigns to test the validity of this assumption.

[38] Figure 9 compares the longitudinal trends in grain size of various sediment sample series. Particularly in the topset part of the reservoir dominated by sand and gravel, median grain size $\left(\mathrm{D}_{50}\right)$ changes rapidly downstream. The most significant change in region-averaged grain size (from sand- to silt-sized sediment) occurs in the middle of the reservoir between coring sites 7 and 4, which corresponds to the steep change in water depth and sediment thickness at the front of the reservoir delta (Figures 5 and 9). We expected this important transition from the outset, hence the relatively close spacing of deep coring sites through the foreset region of the reservoir deposit. In the distal, finegrained part of the reservoir, $\mathrm{D}_{50}$ is relatively constant. The monotonic downstream-fining trends of the region-averaged samples suggest that an increased number of deep-coring sites in the longitudinal direction would only refine, not fundamentally change, our estimates of overall properties.

[39] Across-channel variability in grain size can be evaluated using sediment samples from three transects of gravity and box cores (Figure 10). One goal of this analysis is to quantify the degree of variability in the grain size in the transverse direction; another is to determine whether the deep coring sites (generally close to the predam channel thalweg) are likely to be representative of the entire cross section. In particular, one might hypothesize that there may be some fining of material near the sides of the channel due to reduced transport capacity away from the deepest part of the channel, particularly in the upstream, bed load-dominated part of the reservoir. Indeed, over the short transverse distance $(\sim 20 \mathrm{~m}$ (Figure 10b)) of the four boreholes at the base of the delta front (site 4) variations in grain size within some correlated sandy layers can be identified visually (e.g., stratigraphic columns in Snyder et al. [2004b]). However, these minor variations between the nearby boreholes should introduce only random error in the composite subsample series, because during subsampling no preference was given to layers based on grain size, but rather the objective was to obtain the most stratigraphically continuous section.

[40] The box cores sampled only the top $\sim 12 \mathrm{~cm}$ of lake sediments. In 2002, throughout the reservoir (Figure 9) this uppermost interval was dominated by fine-grained sediment because of the relatively long time interval since the last large flood (January 1997). During the autumn of 1997, the reservoir was drawn down about $10 \mathrm{~m}$, which may have contributed to resuspension and transport of the flood deposit. Seven of the gravity cores at sites 10 and 12 (deep coring sites 4 and 9 respectively (Figures 4 and 10)) penetrated a sand layer (probably from 1997) below the surficial fines, which is likely more representative of the sediment deposited and preserved in the topset region 


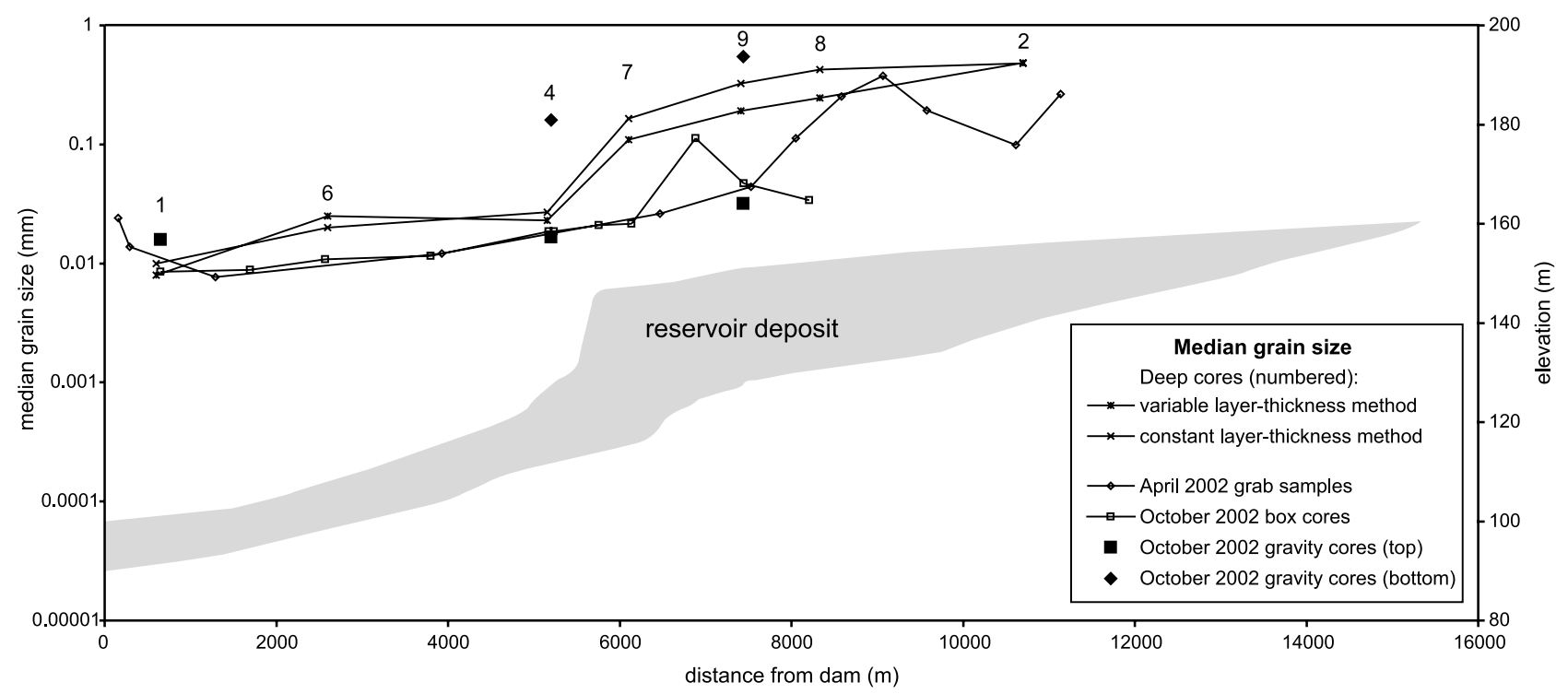

Figure 9. Longitudinal changes in median grain size of sediment. See Figure 4 for core locations. The legend is for site-averaged sediment samples (grain-size scale on left axis). For reference the reservoir deposit (Figure 5) is shown schematically, with the elevation scale plotted on the right axis.

(Figures 5 and 9). The gravity cores were subsampled specifically to compare sedimentary layers across the channel: the top subsamples contain only the fine-grained, surficial layer, similar to the box cores; the bottom subsamples include only the sandy material (Figure 10). Therefore these samples are likely from the same depositional events, and are directly comparable from core to core. At each of the three transects the surficial fine layers show about a twofold variability in $\mathrm{D}_{50}$ across the channel. The surficial data in the topset transect (gravity coring site 12) shows a modest fining trend from the center to both sides, whereas the data from sites 11 and 10 show little evidence for systematic fining to the banks. At site 12 the sand layer has a twofold variation amongst the three subsamples, with the coarsest sand $\left(D_{50}=0.67 \mathrm{~mm}\right)$ closer to the north (river right) bank, which is the outside of a bend. In the foreset transect (site 10), $\mathrm{D}_{50}$ varies little amongst the three sand subsamples $(0.14-0.16 \mathrm{~mm})$. The sand layer data set is small, does not extend to the reservoir banks, and is therefore only of limited use in examining lateral fining.

[41] The available data indicate that grain size varies in the transverse direction more in the upstream part of the reservoir, which is consistent with the hypothesis that channelized flow is more common in the narrower, shallower, topset region. Therefore we suggest the caveat that, particularly in the proximal part of the deposit, our estimates may be biased toward coarse grain size due to lack of sampling of finer sediments along the edges. However, the data do not show large, systematic intralayer changes in grain size (i.e., from sand to silt) toward the reservoir margins that would bias our estimates significantly; if such changes occur they are likely to be restricted to a volumetrically small portion of the deposit. Furthermore, we see no evidence from the shallow-core transects that the specific positions of deep core sites 1, 4, and 9 should be preferentially coarse or fine with regard to overall transverse variations.

\subsubsection{Analytical Uncertainty}

[42] All of the individual analyses of reservoir sediment properties have associated uncertainties, many of which can be quantified. We are most concerned with errors that may not be normally distributed because these could introduce systematic biases in the data. Normally distributed errors should affect the overall estimate of reservoir sediment properties, but are likely to be insignificant when compared to the sampling and stratigraphic uncertainties discussed above.

[43] Wet bulk density was measured with a multisensor core logger, which was calibrated to water and aluminum standards at regular time intervals. The calibration tolerance was $1 \%$, which gives an estimate of the analytical uncertainty for the instrument [Snyder et al., 2004b]. However, a greater source of uncertainty in the density values comes from disturbance of the sediments in core liners. Expansion of biogenic gas (probably methane-rich) stored in the finegrained sediments was common; sometimes increasing the volume of cored material by as much as $10 \%$. Presumably this would correspond to a decrease in wet bulk density $\left(\rho_{\mathrm{w}}\right)$ from that of in situ reservoir material. However, this effect is likely smaller than $10 \%$ overall because: (1) it only occurred in fine-grained sediments; and (2) often the expansion was expressed as distinct cracks with low-density values $(<1 \mathrm{~g} /$ $\mathrm{cm}^{3}$ ) that were edited from the data set [Snyder et al., $2004 b]$. Nonetheless, the $\rho_{\mathrm{w}}$ values may slightly underestimate the density of in situ reservoir sediments. The conversion from $\rho_{\mathrm{w}}$ to $\rho_{\mathrm{d}}$ also introduces some uncertainty, as indicated by the scatter on Figure 8 , although the strong correlation between the variables suggests that the relationship is not likely to be an important source of nonrandom error in the analysis.

[44] Snyder et al. [2004a] present and discuss the analytical errors for loss on ignition (LOI) and grain-size distribution, based on replicate analyses. Here we summarize these results. The LOI analyses of the composite samples agreed within \pm 0.45 weight percent based on the absolute 
A. Deep core site 1 (shallow core site 11)

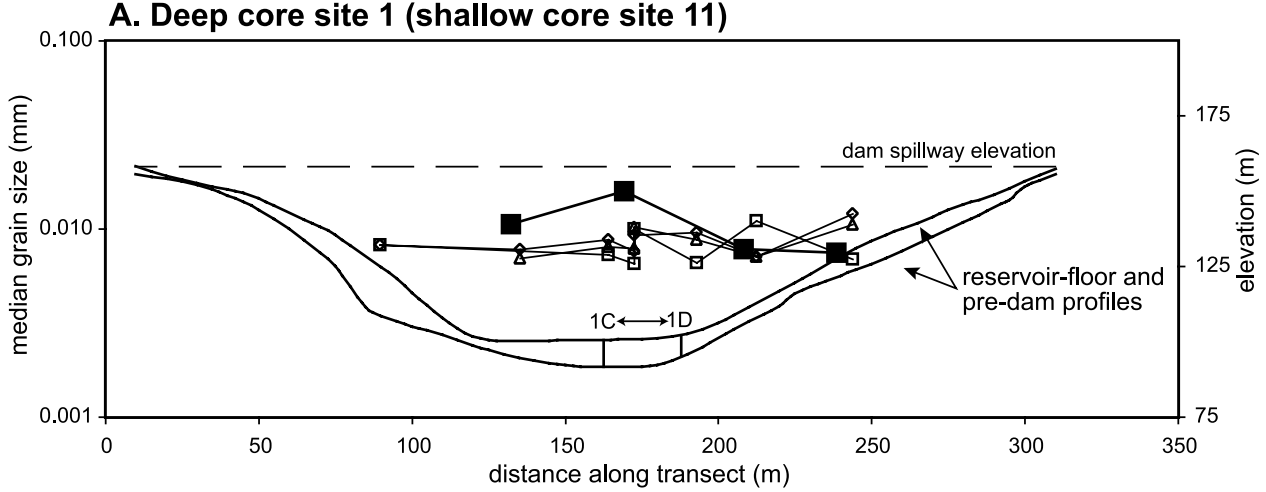

B. Deep core site 4 (shallow core site 10 )

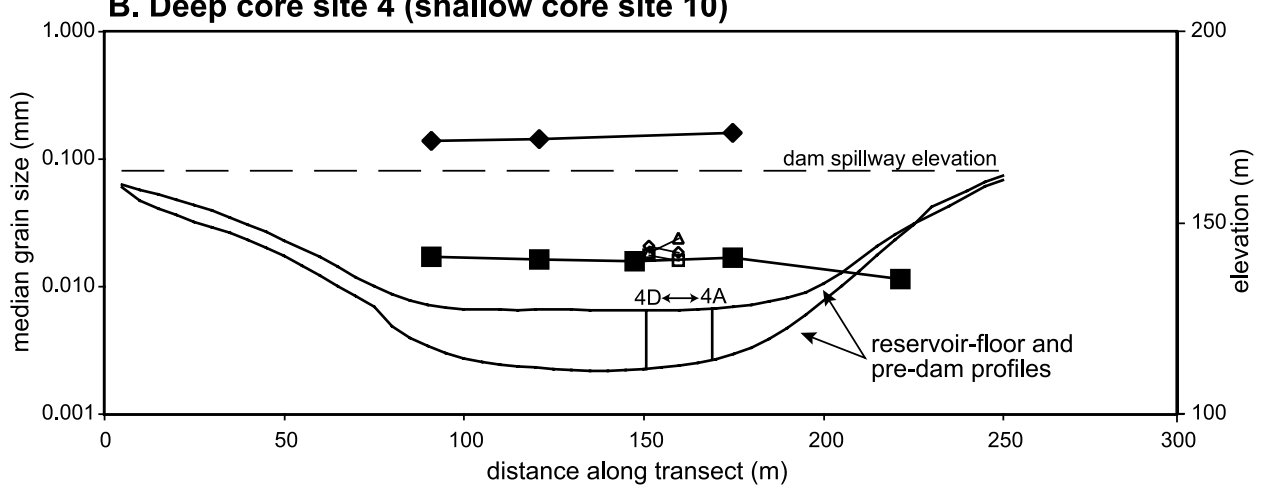

\section{Deep core site 9 (shallow core site 12)}

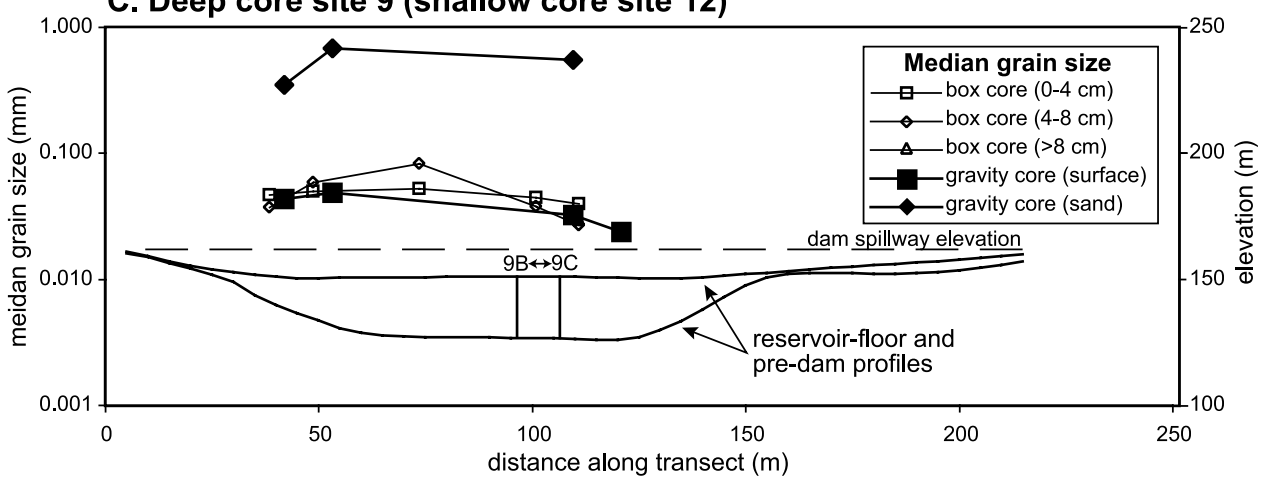

Figure 10. Transverse changes in sediment median grain size. All grain-size data (left axis) is from gravity and box cores taken in October 2002 [Snyder et al., 2004a]. See Figure 4 for core locations. The west or north (river right) bank of the reservoir is plotted on the left side of the graphs. The legend in Figure 10c applies to all three graphs. For reference, transverse predam and reservoir floor profiles (solid lines; right axis) and water surface elevation (dashed lines; right axis) are shown. Vertical bars between the surfaces indicate the approximate transverse range of locations of deep cores taken at each site. Note that all scales change between the three graphs. (a) Shallow core series 11, near deep drilling site 1. (b) Shallow core series 10, near deep drilling site 4. (c) Shallow core series 12, near deep drilling site 9.

value of the difference between 69 replicate pairs (with a mean value of $5.82 \% \mathrm{LOI})$. In samples that contained no gravel (material $>2 \mathrm{~mm}$ ), the median grain size of 15 composite series replicate pairs was $\pm 0.10 \varnothing$ or a relative percent difference (absolute value of the difference between replicate pairs divided by the mean) of the sample size in $\mathrm{mm}$ of $6.6 \%$. The percent within each grain-size class agrees within $2.7 \%$ (for sand) to $0.5 \%$ (for clay). Gravel posed a problem for the replicate analyses because individual particles might make up such a large part of total weight of each of the replicates. When 10 replicate pairs of samples that contain some gravel are included in the in error analysis, the median grain size varies by $0.25 \varnothing$ or $16.4 \%$, and percent in each size category ranges from $8.6 \%$ (gravel) 
to $0.6 \%$ (clay). These analytical errors are important for each individual analysis of sedimentary units within the cores, but for calculations of overall reservoir sediment quantities such normally distributed errors should be unimportant compared to the relatively large uncertainties related to extrapolation and estimation.

\subsubsection{Extrapolation Methods}

[45] The two methods used to extrapolate from a composite borehole section to an entire three-dimensional reservoir volume (Figure 6) yield slightly different grain-size estimates (Tables $3 \mathrm{a}$ and $3 \mathrm{~b}$ ). The variable layer thickness method assumes that the proportion of each layer represented by the composite borehole sections is representative of the entire region, whereas the constant layer thickness method assumes that the reservoir fills from the bottom up and therefore emphasizes the top layers. The former is more consistent with deposition by settling out of suspension from the entire water column, the latter with channelized flow along the lake floor. In the downstream regions (Figure 10a), the relatively thick deposits on the flanks of the reservoir suggest that settling out of suspension is an important process because deposition is not particularly concentrated in the predam river thalweg. In the upstream regions (Figure 10c), the thickest deposits are clearly found in the thalweg, suggesting that channelized, bottom-up processes are important. Because of the relatively homogeneous nature of the distal, fine-grained deposits with depth, the two methods differ little in the downstream part of the reservoir (regions 1, 6 and 4). Indeed, a hybrid extrapolation model using the constant layer thickness method in the upstream part of the reservoir, and the variable layer thickness method in the downstream part yields mass and grain size results that are within $0.5 \%$ of the constant layer thickness method. Therefore the constant layer thickness method is a somewhat better estimate because it may be more consistent with the likely dominant depositional process in the part of the reservoir where the extrapolation methods differ. The overall close agreement in between the two methods suggests that the estimates appear robust regardless of methodology used. However, both methods use the same set of input data (the composite borehole sections), and therefore the limitations discussed above (trap efficiency, grain-size variability, and analytical uncertainties) apply to both. In particular, nonrandom errors such as lateral fining and density changes due to gas expansion would affect the estimates from either extrapolation method. In the conclusions (below), the extrapolation methods are discussed in the context of other reservoir settings.

\subsection{Implications for the Upper Yuba River Studies Program}

[46] This study represents an important step in assessing the current conditions in Englebright Lake for the Upper Yuba River Studies Program (UYRSP). The overall contents of the reservoir, as calculated here, combined with detailed vertical grain-size sections [Snyder et al., 2004a] provide a data set critical to modeling the transport of sediment into and through the reservoir under various dam management scenarios. These include leaving the dam in place, reducing its height, or full decommissioning (removal) over time. Detailed grain-size information is vital to forecasting the outcome of these scenarios. First, the grain-size distribution dictates the choice of transport mod- els to use. The sedimentologic results present here indicate that Englebright Lake will require a mixed-size model, capable of treating fine sediment, sand and gravel, and bed evolution [e.g., Wilcock and Crowe, 2003]. Second, an important constraint for all scenarios is that downstream flood risk not be increased. This requirement might be violated if release of the considerable quantity of coarse sand and gravel stored in the reservoir were to raise river bed elevations due to sediment deposition as the river gradient decreases in the Central Valley. Third, grain-size information is critical to forecasting the transport and fate of chemical species stored in the reservoir, particularly mercury, which is primarily associated with finer grain sizes [Domagalski et al., 2000; Hunerlach et al., 2004] (see http://water.usgs.gov/pubs/circ/circ1215). Finally, the results of this study present a means to calibrate and verify Yuba River sediment transport models by attempting to reconstruct the present, observed reservoir deposit using the hydrologic record as a model input. The data presented here are crucial to answering scientific and management questions in the specific case of the Yuba River system, and also to understanding the impact of reservoir storage on the sediment budget of the overall Sacramento River system, as investigated by Wright and Schoellhamer [2004]. This work is an early step in the scientific investigations of the UYRSP; a base for further studies; it would be premature to predict the outcome of reservoir management scenarios based solely on these results.

\subsection{Suggestions for Future Reservoir Studies}

[47] As decommissioning of large dams becomes a more common management option [e.g., Pejchar and Warner, 2001; Aspen Institute, 2002; Hart and Poff, 2002; Heinz Center, 2002; Doyle et al., 2003], studies of the type described here will be increasingly necessary. Many of the reservoir sedimentologic data sets presented here are expensive to collect, particularly the deep cores. With this in mind, we offer a few brief suggestions that might be useful to future studies.

\subsubsection{Repeat Bathymetric Surveys}

[48] Most U.S. dams built during the middle part of the 20th century will have high-quality topographic maps available for the predam reservoir area, as was the case for Englebright Dam (from the U.S. Army Corps of Engineers). Childs et al. [2003] demonstrated the power and utility of simply differencing digital versions of the predam and present-day topography to calculate volumes of sediment deposited. Using digital acoustic fathometers and differential global positioning systems (DGPS), bathymetric surveys are now relatively easy and inexpensive to collect, and should be done early in the process of designing a large investigation of sediment deposition in a reservoir. In particular, a precise, digital isopach map is critical for imaging the deltaic structure, and for citing coring locations using real-time DGPS. In this study, we used the isopach map [Childs et al., 2003] to direct coring near the predam river thalweg, and thereby sample maximum postdam sediment thickness at each location. We were also able to identify in advance, and sample, the thickest section of deposition (site 7 (Figure 4)).

[49] Bathymetric surveys also present an excellent opportunity to understand depositional processes. Reservoirs where bathymetric surveys have been repeated over their 
history present a particularly exciting opportunity to investigate the evolution of a reservoir deposit [e.g., Smith et al., 1960; Morris and Fan, 1998; Dunbar et al., 1999]. Moreover, high-resolution bathymetric surveying equipment is becoming more available and more commonly used [e.g., Gardner et al., 2000]. The morphologic and subbottom information gained from such high-resolution surveys (horizontal resolution $<1 \mathrm{~m}$ ), including imaging of bed forms, would be vastly superior to that collected by traditional fathometry. To use the example of this study, highresolution data might be able to provide insight into process-oriented questions related to the three-dimensional morphology of the topset region and delta front (channeled or unchanneled?), and the existence of bed forms in the bottomset beds consistent with deposition by turbidity currents [Kostic et al., 2002].

\subsubsection{Geophysical Data Sets}

[50] As discussed here and elsewhere [Childs et al., 2003], high-resolution images of reservoir subbottom structure from seismic reflection or ground-penetrating-radar surveys would be extremely valuable. Unfortunately, several attempts with a variety of instruments to collect such data in Englebright Lake were unsuccessful, likely due to the presence of biogenic gas in the sediments and the steep, narrow reservoir shape [Childs et al., 2003]. This lack of success should not preclude similar surveys; other reservoirs have yielded much better results [e.g., Twichell et al., 2003, 2005] (see http://pubs.usgs.gov/of/2003/of03-320). Seismic stratigraphy would be invaluable for reconstructing the three-dimensional structure of the reservoir deposit, its depositional history, and correlating stratigraphic surfaces between the cores.

[51] Another valuable geophysical technique is borehole logging with tools that yield a record of sediment physical and chemical properties (e.g., natural gamma radiation and electrical resistivity). During the deep coring campaign at Englebright Lake, we experimented with geophysical logs in boreholes that were unlined (risking loss of tools if the hole collapsed), and boreholes lined with steel well casing or PVC pipes. Typically we logged one of the boreholes at each of the seven deep coring sites [Snyder et al., 2004b, Figure 4]. In retrospect, all of the boreholes in Englebright Lake should have been lined with PVC pipe (which was the most effective technique) and logged immediately after coring to provide directly intercomparable data sets. Lining and logging the completed boreholes with one tool added 1-3 hours to the drilling process, a relatively minor investment in time. Because the PVC pipe was recovered and reused, the additional materials cost was also minor. Borehole logging has the distinct advantage over coring in that the data collected is continuous through the entire sediment section. This might allow for better opportunities to correlate stratigraphy among parallel boreholes at one coring location, and between coring locations.

\subsubsection{Coring Suggestions}

[52] Mobilization of a rig capable of coring through tens of meters of fine and coarse sediment is expensive and challenging [Dean et al., 2002; Snyder et al., 2004b]. As a result, efforts should be made to maximize the information gained from the minimum number of boreholes. For the case of Englebright Lake, we emphasized coverage in the longitudinal direction, because the reservoir is so narrow.
We gained complementary information about transverse variability with gravity cores [Snyder et al., 2004a], which are much less expensive to collect. More extensive cross sections with gravity cores (i.e., to both sides of the reservoir) would be useful. The utility of gravity cores is limited by their inability to penetrate coarse-grained sediments very well [e.g., Gould, 1960]. Because grab samples and gravity cores are relatively simple to collect, this should be done early in the planning process of a reservoir sedimentation survey, around the same time as bathymetric mapping. Basic information about the downstream changes in grain size, in particular from sand and gravel to silt and clay, is valuable to maximize the efficiency of deep coring.

[53] Elsewhere, we have discussed the difficulty of penetrating and recovering unconsolidated coarse sand and gravel from reservoir deposits [Snyder et al., 2004b]. Vibracoring might present an alternative means for sampling in similar grain sizes, although this technique is not capable of penetrating the thicknesses of sediment found in Englebright Lake. In most cases, we found that a trial-anderror approach using hydraulic piston coring, and optimizing the concentration of drilling mud and length of each push was the best means for increasing recovery.

\section{Summary and Conclusions}

[54] Reservoir sedimentation studies hold the promise for improving our understanding of transport rates and depositional systems because they offer the opportunity to observe changes over decadal (or less) timescales. This study was concerned with quantifying the mass and grain size of the sediment deposited behind Englebright Dam to: (1) present basic data on watershed-transport rates; (2) inform habitat restoration-related investigations in the Yuba River; and (3) provide an example for future, similar studies of reservoirs.

[55] During 61 years of dam operations (from 1940 to 2001), Englebright Lake accumulated $21.9 \times 10^{6} \mathrm{~m}^{3}$ of sediment, which occupies $25.5 \%$ of the original storage capacity. The accumulated material is deposited in a long, narrow delta, with upstream topset beds dominated by coarse sand and gravel, prograding foreset beds dominated by sand, and bottomset beds containing silt, clay and fine sand.

[56] Extrapolation of from a vertical composite borehole stratigraphy to a three-dimensional region was done using two methods, assuming variable or constant layer thickness. These methods yield nearly identical estimates of the mass of the reservoir deposit $\left(25.5-25.6 \times 10^{6} \mathrm{t}\right)$, and only slightly differing grain-size distributions $(64.7-68.5 \%$ sand and gravel). These similarities show that calculations of reservoir quantities are not particularly sensitive to extrapolation methodology. Other reservoirs with more complicated geometry or spatially heterogeneous sedimentology might exhibit greater differences between these extrapolation methods. We suggest that the constant layer thickness method is probably most applicable to the stratigraphy observed in Englebright Lake, particularly in the bed load-dominated, coarsening-upward foreset and topset regions. Further, we expect that this method would be superior in many high-relief reservoir settings where coarse sediment is transported along the reservoir floor during events (bed load, turbidity currents), resulting in strong 
vertical variations in grain size. Either method can be easily applied to other reservoirs provided borehole spacing is sufficient to capture the three-dimensional variability in sediment properties.

[57] The large amount of gravel stored in the reservoir ( $\sim 19 \%$ of the total deposit) suggests that bed load transport is quite significant in the Yuba River, and has implications for modeling of sediment transport under future dam management scenarios in this system. Assuming no contribution of sediment from upstream areas impounded by other dams, the basin-wide sediment yield to Englebright Lake is $\sim 340 \mathrm{t} / \mathrm{km}^{2} / \mathrm{yr}$, which is at the high end of the range for other regional reservoirs, not surprising given the history of hydraulic mining in the watershed.

[58] Although this is an extremely well-constrained reservoir deposit, considerable uncertainties in the overall quantities exist. The primary source of uncertainty is the lack of sampling from the upstream, proximal part of the delta, which contains mostly sand and gravel, although the relative quantities of each are poorly constrained. The problem of poor recovery of sediment in coarse, upstream areas is likely to be common in many reservoir coring efforts [e.g., Smith et al., 1960], particularly in mountainous settings. Other limitations include reservoir trap efficiency, possibly nonrepresentative core sampling due to lateral variability in deposit properties, and analytical uncertainties, although these probably introduce relatively minor errors compared to the unsampled regions. This study represents a type of investigation that is likely to increase in frequency as the world's dams continue to age.

[59] Acknowledgments. The authors wish to thank the following people for assistance in the field and laboratory: Margaret Hampton (USGS, Santa Cruz); Connie Clapton, Michael Hunerlach, and Benjamin Wilkins (USGS, Sacramento); Brian Haskell (University of Minnesota); Kevin Knutson (USGS, Portland); James Allen, Carlin Dare, Heather Harms, Andrew Matthew, Mark Marvin-DiPasquale, Gary Schneider, Helen Tai, Michael Torresan, and Ryan Wooley (USGS, Menlo Park); and the staffs of DOSECC Incorporated and Skippers Cove Marina. Discussions with David Topping (USGS, Flagstaff) and Bill Normark (USGS, Menlo Park) aided in focusing the analyses presented herein. This manuscript benefited from three anonymous reviews and from comments on an earlier draft by Bruce Jaffe and Jonathan Warrick. This work was funded by the California BayDelta Authority (CALFED) Ecosystem Restoration Program and a CALFED Science Fellows Program award to N.P.S.

\section{References}

Alpers, C. N., and M. P. Hunerlach (2000), Mercury contamination from historic gold mining in California, U.S. Geol. Surv. Fact Sheet, FS 0061$00,6 \mathrm{pp}$.

Ambers, R. K. R. (2001), Using the sediment record in a western Oregon flood-control reservoir to assess the influence of storm history and logging on sediment yield, J. Hydrol., 244, 181-200.

Aspen Institute (2002), Dam Removal: A New Option for a New Century, 68 pp., Washington, D. C.

Brown, C. B. (1943), Discussion of sedimentation in reservoirs, Proc. Am. Soc. Civ. Eng., 69, 1493-1500.

Brune, C. B. (1953), Trap efficiency of reservoirs, Eos Trans. AGU, 34, 407-418.

Childs, J. R., N. P. Snyder, and M. A. Hampton (2003), Bathymetric and geophysical surveys of Englebright Lake, Yuba-Nevada Counties, California, U.S. Geol. Surv. Open File Rep., 03-383, 20 pp.

Dadson, S. J., et al. (2003), Links between erosion, runoff variability and seismicity in the Taiwan orogen, Nature, 426, 648-651.

Dean, W., J. Rosenbaum, B. J. Haskell, K. R. Kelts, and D. W. Schnurrenberger (2002), Progress in global lake drilling holds potential for global change research, Eos Trans. $A G U, 83,85-91$.
Dendy, F. E., and W. A. Champion (1978), Sediment deposition in U.S. reservoirs: Summary of data reported through 1975, U.S. Dept. Agric. Misc. Publ., 1362, 84 pp.

Domagalski, J. L., D. L. Knifong, P. D. Dileanis, L. R. Brown, J. T. May, V. Connor, and C. N. Alpers (2000), Water quality in the Sacramento River basin, California, 1994-98, U.S. Geol. Surv. Circ., $1215,36 \mathrm{pp}$.

Doyle, M. W., E. H. Stanley, J. M. Harbor, and G. E. Grant (2003), Dam removal in the United States: Emerging needs for science and policy, Eos Trans. $A G U, 84,29-36$

Dunbar, J. A., P. M. Allen, and P. D. Higley (1999), Multifrequency acoustic profiling of water reservoir sedimentation studies, J. Sediment. Res., $69,521-527$.

Gardner, J. V., L. A. Mayer, and J. E. Hughs Clarke (2000), Morphology and processes in Lake Tahoe (California-Nevada), Geol. Soc. Am. Bull., $112,736-746$.

Gilbert, G. K. (1917), Hydraulic-mining débris in the Sierra Nevada, U.S. Geol. Surv. Prof. Pap., 105, 154 pp.

Gould, H. R. (1960), Amount of sediment, U.S. Geol. Surv. Prof. Pap., 295, $195-200$.

Grant, G. E., J. C. Schmidt, and S. L. Lewis (2003), A geological framework for interpreting downstream effects of dams on rivers, in A Unique River, edited by J. E. O’Connor and G. E. Grant, pp. 209-225, AGU, Washington, D. C.

Hart, D. D., and N. L. Poff (2002), A special section on dam removal and river restoration, BioScience, 52, 653-655.

Heinemann, H. G. (1981), A new sediment trap efficiency curve for small reservoirs, Water Resour. Bull., 17, 825-830.

Heinz Center (2002), Dam Removal: Science and Decision Making, 221 pp., H. John Heinz III Cent. for Sci. Econ. and the Environ., Washington, D. C.

Hunerlach, M. P., C. N. Alpers, M. C. Marvin-DiPasquale, H. E. Taylor, and J. F. De Wild (2004), Geochemistry of fluvial sediment impounded behind Daguerre Point Dam, Yuba River, California, U.S. Geol. Surv. Sci. Invest. Rep., 2004-5165.

James, L. A. (1993), Sustained reworking of hydraulic mining sediment in California: G. K. Gilbert's sediment wave model reconsidered, Zeitschr. Geomorphol. Suppl., 88, 49-66.

James, L. A. (1999), Time and persistence of alluvium: River engineering, fluvial geomorphology, and mining sediment in California, Geomorphology, 31, 265-290.

James, L. A. (2004), Sediment from hydraulic mining detained by Englebright and small dams in the Yuba Basin, Geomorphology, in press.

Kostic, S., G. Parker, and J. G. Marr (2002), Role of turbidity currents in setting the foreset slope of clinoforms prograding into standing fresh water, J. Sediment. Res., 72, 353-362.

Magilligan, F. J., K. H. Nislow, and B. E. Graber (2003), Scale-independent assessment of discharge reduction and riparian disconnectivity following flow regulation by dams, Geology, 31, 569-572.

Morris, G. L., and J. Fan (1998), Reservoir Sedimentation Handbook: Design and Management of Dams, Reservoirs, and Watersheds for Sustainable Use, 848 pp., McGraw-Hill, New York.

Noren, A. J., P. R. Bierman, E. J. Steig, A. Lini, and J. Southon (2002), Millennial-scale storminess variability in the northeastern United States during the Holocene epoch, Nature, 419, 821-824.

Pejchar, L., and K. Warner (2001), A river might run through it again: Criteria for consideration of dam removal and interim lessons from California, Environ. Manage., 28, 561-575.

Rockwell, G. L., J. R. Smithson, M. F. Friebel, and M. D. Webster (2002), Water Resources Data California Water Year 2001, vol. 4, Northern Central Valley Basins and the Great Basin from Honey Lake Basin to Oregon State Line, U.S. Geol. Surv. Water Data Rep. CA-01-4, 482 pp., U.S. Geol. Surv., Washington, D. C.

Rubin, D. M., D. J. Topping, J. C. Schmidt, J. Hazel, M. Kaplinski, and T. S. Melis (2002), Recent sediment studies refute Glen Canyon Dam hypothesis, Eos Trans. $A G U, 83,273,277-278$.

Smith, W. O., et al. (1960), Comprehensive survey of sedimentation in Lake Mead, 1948-49, U.S. Geol. Surv. Prof. Pap., 295, 254 pp.

Smithson, J. R., M. F. Friebel, M. D. Webster, and G. L. Rockwell (2003), Water Resources Data California Water Year 2002, vol. 4, Northern Central Valley Basins and the Great Basin from Honey Lake Basin to Oregon State Line, U.S. Geol. Surv. Water Data Rep. CA-02-4, 495 pp., U.S. Geol. Surv., Washington, D. C.

Snyder, N. P., and M. A. Hampton (2003), Preliminary cross section of Englebright Lake sediments, U.S. Geol. Surv. Open File Rep., 03397, 1 p. 
Snyder, N. P., J. R. Allen, C. Dare, M. A. Hampton, G. Schneider, R. J. Wooley, C. N. Alpers, and M. C. Marvin-DiPasquale (2004a), Sediment grain-size and loss-on-ignition analyses from 2002 Englebright Lake coring and sampling campaigns, U.S. Geol. Surv. Open File Rep., 2004-1080, 46 pp.

Snyder, N. P., C. N. Alpers, J. A. Curtis, L. E. Flint, M. A. Hampton, B. J. Haskell, and D. Nielson (2004b), Report on the May-June 2002 Englebright Lake deep coring campaign, U.S. Geol. Surv. Open File Rep., 2004-1061, 32 pp.

Syvitski, J. P. M. (2003), Supply and flux of sediment along hydrological pathways: Research for the 21st century, Global Planet. Change, 39, $1-11$.

Twichell, D. C., V. A. Cross, and S. D. Belew (2003), Mapping the floor of Lake Mead (Nevada and Arizona): Preliminary discussion and GIS data release, U.S. Geol. Surv. Open File Rep., 03-320.

Twichell, D. C., V. A. Cross, A. Hanson, B. Buck, J. Zybala, and M. R. Rudin (2005), Seismic architecture and lithofacies of turbidites in Lake Mead (Arizona and Nevada, USA): An analogue for topographically complex basins, J. Sediment. Res., 75, 135-149.

Verstraeten, G., and J. Poesen (2000), Estimating trap efficiency of small reservoirs and ponds: Methods and implications for the assessment of sediment yield, Prog. Phys. Geogr., 24, 219-251.

Verstraeten, G., and J. Poesen (2001), Variability of dry sediment bulk density between and within retention ponds and its impact of the calculation of sediment yields, Earth Surf. Processes Landforms, 26, $375-394$.

Verstraeten, G., J. Poesen, J. de Vente, and X. Koninckx (2003), Sediment yield variability in Spain: A quantitative and seimiquantitative analysis using reservoir sedimentation rates, Geomorphology, 50, $327-348$.

Vörösmarty, C. J., M. Meybeck, B. Fekete, K. Sharma, P. Green, and J. P. M. Syvitski (2003), Anthropogenic sediment retention: Major global impact from registered river impoundments, Global Planet. Change, 39, $169-190$

Wilcock, P. R., and J. C. Crowe (2003), Surface-based transport model for mixed-size sediment, J. Hydraul. Eng., 129, 120-128.

Wolman, M. G. (1954), A method of sampling coarse river-bed material, Eos Trans. $A G U, 35,951-956$.

Wright, S. A., and D. H. Schoellhamer (2004), Trends in the sediment yield of the Sacramento River, California, 1957-2001, San Francisco Estuary Watershed Sci., 2, article 2.

C. N. Alpers, J. A. Curtis, and L. E. Flint, U.S. Geological Survey, Placer Hall, 6000 J Street, Sacramento, CA 95819, USA. (cnalpers@usgs.gov; jacurtis@usgs.gov; lflint@usgs.gov)

J. R. Childs, U.S. Geological Survey, MS 999, 345 Middlefield Road, Menlo Park, CA 94025, USA. (jchilds@usgs.gov)

D. M. Rubin, Pacific Science Center, U.S. Geological Survey, 400 Natural Bridges Drive, Santa Cruz, CA 95060, USA. (drubin@usgs.gov)

N. P. Snyder, Department of Geology and Geophysics, Boston College, 140 Commonwealth Avenue, Chestnut Hill, MA 02467, USA. (noah. snyder@bc.edu)

S. A. Wright, U.S. Geological Survey, 2255 N. Gemini Drive, Flagstaff, AZ 86001, USA. (sawright@usgs.gov) 